\title{
The Adjudication of Commercial Disputes within the Dutch Community
}

\author{
1 \\ Adjudication amongst Peers: The Use of Arbitration
}

\subsection{The Friendly Settlement of Local Troubles}

As discussed in the first chapter of this book, the Dutch merchant community of Izmir was small, and merchants lived near one another around or on the so-called 'Street of the Franks' (see figure 4). While they certainly interacted with one another socially, Dutch traders in Izmir generally did not do business together. While Dutch commercial firms in Izmir certainly did favours for one another, their never-ending quest to obtain new commissions from their peers in the United Provinces or elsewhere also made them competitors. The only exception in this competition between peers was the establishment of an intra-Dutch partnership - and for long periods of time, some Dutch merchants were affiliated with one another before going their separate ways again. Firms such as Knipping \& Ouckama; Lennep, Enslie \& Knipping; and Clement, van Sanen, van der Zee \& $\mathrm{C}^{\circ}$ were all partnerships between Dutch traders, although their constellations varied over time, with some partners leaving to set up their own firms while others were fired. In 1753, for instance, the partnership of Belcamp, Begler \& Clement figured on a list of Dutch firms in Izmir. The same list featured both Dirk Knipping and Pieter van Sanen as independent merchants. ${ }^{1}$ The next year, Knipping partnered with David van Lennep, and van Sanen joined the partnership of Belcamp and Clement, while Begler di Joseph no longer appeared as a partner. In 1755, the partnership of van Lennep and Knipping was joined by William Enslie, while Belcamp, Clement \& van Sanen continued to be in business together. In 1757 , Belcamp ceased to be a partner, and in 1758, Knipping was fired from the partnership, leaving only van Lennep \& Enslie. ${ }^{2}$ In 1759, Knipping established a new partnership with Pieter Ouckama, a partnership that was dissolved in

1 Heeringa and Nanninga, Bronnen tot de geschiedenis, 3: pp. 778-783, 'De Nederlandsche handelshuizen te Smirna'; see also table 2.

2 Knipping was fired because he had married a Greek woman. See pp. 70-71. 
1762. In 1763, the partnership of Clement \& van Sanen became Clement, van Sanen, van der Zee \& $\mathrm{C}^{\circ} .^{3}$

These changing constellations show the fragile nature of partnerships within the Dutch trading community of Izmir. Sometimes, these came about as calculated associations between established traders, but it was also possible for a younger merchant already employed by the firm as a scribe or accountant to be promoted to partner. Some of these partnerships worked well for several years, while others dissolved rapidly, sometimes following disputes between the partners or their representatives. Apart from forming partnerships, Dutch firms in the Levant regularly accepted employees to learn the specifics of Levant trade. These apprentices could be younger sons of well-established firms or simply young men aiming at a career of their own, but some of them never left the firm and remained employees for a long time. Several of Izmir's larger Dutch firms employed such men as accountants or scribes. ${ }^{4}$ The list of the Dutch inhabitants of Izmir in 1759 contains the name of Arnoldus Wissing, who was a scribe (see table 2). According to the list, he had married a French woman and had been residing in Izmir for twelve years. He must have worked for the Dutch firm of Clement, van Sanen, van der Zee \& $\mathrm{C}^{\circ}$ since his arrival, because in 1771, he wrote that he had been in their service for twenty-five years, corresponding more or less with his arrival in 1747 - twelve years prior to $1759 .{ }^{5}$ In 1760, Wissing travelled to Egypt on a mission to establish a branch of the firm Clement, van Sanen, van der Zee \& $\mathrm{C}^{\circ}$ in Cairo. In September of that year, the Dutch ambassador in Istanbul informed the States General that the Ottoman Porte had granted protection to Wissing, which enabled him to undertake the voyage to Cairo. ${ }^{6}$ The venture did not work out, and Wissing's actions in Egypt were not appreciated by Robert Hughes, acting Dutch consul in Egypt at the time. ${ }^{7}$ Following the debacle, Wissing seems to have gone back to Amsterdam, where he had been born. In 1763, a contract for six years was drafted before an Amsterdam notary in which Wissing, for a yearly salary of 750 guilders, was to

3 Heeringa and Nanninga, Bronnen tot de geschiedenis, 3: pp. 778-783, 'De Nederlandsche handelshuizen te Smirna'.

4 See tables 2 and 3 .

5 NACs, $\mathrm{N}^{\circ} 348$ ('Proces van N: van der Zee \& $\mathrm{C}^{\circ}$ voor Clement, van Sanen, van der Zee \& $\mathrm{C}^{\circ}$ met A: Wissing van 25 maert tot xbr. 1771'), 'Antwoord Arnoldus Wissing op d'intimatie der sententie van d'arbitter in differentie met Clement van Sanen van der Zee', Izmir, o1/10/1771.

6 Verzameling van geheime brieven van en aan de gezanten der Nederlandsche Republiek, April 1756-April 1762 (The Hague, 1756-1762), 12: n.p., Consul Daniel Jean de Hochepied to the States General, Istanbul, 16/og/176o.

7 Heeringa and Nanninga, Bronnen tot de geschiedenis, 3: pp. 455-462, Robert Hughes to the States General, Alexandria, 15/o3/1762. 
work as an accountant for Clement, van Sanen, van der Zee \& $\mathrm{C}^{\circ}$ in Izmir, where he arrived at the end of January 1764 . Wissing was allowed to conduct some trade affairs for his own benefit, or in commission for the benefit of others, as long as it did not exceed a certain value - in which case he would have to pay half of the profits to the firm. ${ }^{8}$ It seems Wissing's employers were happy with his performance, as in 1766 they gave him power of attorney to act on behalf of the firm instead of Philippe Clement, the firm's main partner. Wissing was instructed to act as Clement would, according to the power of attorney that had been drafted before a French notary in Berlin. The reason this construction was necessary was the appointment of Philippe Clement a year earlier as president of the newly-founded Prussian Royal Levant Company, which had obtained a monopoly on all trade between Prussia and the Levant. His partner Pieter van Sanen was appointed as Prussian consul - later succeeded by the third partner, Nicolas van der Zee. ${ }^{9}$ In December 1767 , several of the scribes working for Clement, van Sanen, van der Zee \& $\mathrm{C}^{\circ}$ testified that Wissing was a well-behaved and honest person, and if required, they were willing to confirm under oath that Wissing, after coming back from Holland, had been the good fortune of the firm. ${ }^{10}$

As had been the case in the past, Wissing's work initially met with the approval of his principals, but things changed when Nicolas van der Zee boarded a Ragusan vessel to sail to Trieste, and from this city he would continue on to Berlin to discuss matters related to the consulship and the Prussian Royal Levant Company. Circumstances at that time were such that Arnoldus Wissing was left alone in charge of the firm in Izmir. Because the firm was so heavily involved in Prussian business, the Dutch consul did not know whether he should still consider it a Dutch firm, and he wrote the States General to ask how to treat Wissing in case the firm got involved in commercial or legal trouble." The Directorate of Levant Trade sent a letter with their advice on the matter to the burgomasters of Amsterdam in February 1770. They decided that Wissing was no longer allowed to benefit from his Dutch status in matters

8 NACs, $\mathrm{N}^{\circ} 348$, 'Contract van Wissing van Amsterdam', Amsterdam, 20/10/1763.

9 NACs, $\mathrm{N}^{\circ} 348$, 'Copye procuratie van Philip Clement in faveur van Arnoldus Wissing', Berlin, 18/08/1766. This controversy must have led to the temporary removal of Philippe Clement from the partnership. See table 3; see also pp. 209-213.

10 NACs, $\mathrm{N}^{\circ} 348$, 'Copye attestatie van de schrijvers van het huijs van Clement van Sanen van der Zee \& Comp in faveur van Arnoldus Wissing', Izmir, 31/12/1767. One of these scribes was Esaias Fercken, who played a role in another dispute, see p. 247.

11 Both Pieter van Sanen and Philippe Clement had already lost their protected status as Dutch nationals in 1765. Heeringa and Nanninga, Bronnen tot de geschiedenis, 4: p. 137, Consul Daniel Jean de Hochepied to Fagel, Izmir, o1/11/1769. 
related to the Prussian consulate, or to the house of Clement, van Sanen, van der Zee \& $\mathrm{C}^{\circ}$, but that his national status could still be used in personal affairs. ${ }^{12}$

They equally informed the burgomasters that both van Sanen and Clement lost their Dutch protection and national status because of their involvement in Prussian trade matters, and van Sanen also needed to give up his assessorship. Nicolas van der Zee, the third partner in the firm, kept his Dutch status, as he was leaving the partnership - although he lost it later nonetheless, as he became Prussian consul after van Sanen. ${ }^{13}$ This departure was confirmed only about a year later, in March 1771, in a request Nicolas van der Zee had filed with the Dutch consul in which he reclaimed certain monies from Wissing on behalf of his former company, because Wissing had not been performing well. ${ }^{14}$ This was about a month prior to van der Zee's request to be relieved of his duties as Prussian consul because his firm was in such turmoil. ${ }^{15} \mathrm{~A}$ direct link between the two requests was never explicitly made by the protagonists, but it is clear that van der Zee attributed the bad state of affairs of the house of Clement, van Sanen, van der Zee \& $\mathrm{C}^{\circ}$ at least partially to Wissing. By the time Wissing was taken to court, van der Zee had left the firm, which is why the plaintiff in the court case was Nicolas van der Zee \& $\mathrm{C}^{\circ}$ on behalf of Clement, van Sanen, van der Zee \& $\mathrm{C}^{\circ}$.

Van der Zee accused Wissing of not having followed his instructions, particularly concerning a parcel of seventy bales of paper and a cargo of 'peauter', or pewter, a tin alloy, often made with lead, used in domestic objects such as cups, pans or bowls. ${ }^{16}$ Van der Zee further accused Wissing of selling at too low a price in order to be able to apply the money as a loan for himself. Van der Zee claimed 3,210 lion dollars from Wissing. For the pewter, he wanted to be reimbursed with the product itself, as the selling price Wissing had obtained was too low, and van der Zee could not justify the sale to his friends, on whose behalf it had been sold. Additionally, he did not know who the buyer was. ${ }^{17}$ Wissing disputed that he had broken the instructions and pointed out that no selling price had been set. He made a counterclaim, which included several current open accounts in his favour, and belated salary payments related to

12 Heeringa and Nanninga, Bronnen tot de geschiedenis, 4: pp. 138-139, Directorate of Levant Trade to the burgomasters of Amsterdam, Amsterdam, 21/02/1770.

13 Ibid.

14 NACs, $\mathrm{N}^{\circ} 348$, 'Request Nicolas van der Zee om liquidatie te vragen aan Arnoldus Wissing van diverse interesten', Izmir, 25/03/1771.

15 See pp. 209-213.

16 J. Hatcher and T.C. Barker, A history of British pewter (London, 1974).

17 NACs, $\mathrm{N}^{\circ} 348$, 'Request Nicolas van der Zee', Izmir, 25/o3/1771. 
his employment as accountant since $1763 \cdot{ }^{18}$ Copies of the contract and of a declaration on his good character made by scribes of Clement, van Sanen, van der Zee \& $\mathrm{C}^{\circ}$, as well as excerpts from correspondence between Wissing and Philippe Clement in Berlin from 1768 were included in the trial files following Wissing's counterclaim, showing he had done nothing wrong.

On 11 April, both parties agreed to solve their dispute through arbitration. In the meantime, a sum of 59 o lion dollars in the hands of Wissing had been sequestered, sparking a reaction from Wissing's French wife that it was her money and could therefore not be subjected to a sequester. ${ }^{19}$ When the Dutch chancellor showed Constanzia Wissing's claim to van der Zee, he responded that he would release the sequester if Arnoldus Wissing was willing to declare under oath that it was his wife's money - a clear example confirming the importance of the oath as a legal instrument of evidence. At the same time that Constanzia's money was sequestered, so was the cargo of pewter, which had been kept in Wissing's house. ${ }^{20}$ Van der Zee argued that the merchandise was not safe in Wissing's house, and he wanted Wissing to be held responsible should something - a fire or anything damaging the pewter - occur. Van der Zee also wanted Wissing to pay a security deposit to the Dutch chancery until the arbitrators had reached a conclusion. ${ }^{21}$

Wissing replied that he was more than happy to pay a security deposit if van der Zee was willing to do the same, writing that his own claim was legally as valid as van der Zee's but that he could neither agree nor disagree on the transport of the pewter, as it had been sold already to an Ottoman subject. ${ }^{22}$ In the end, both conditions, the transport of pewter and the security deposit, were fulfilled, and the arbitrators were chosen by the litigants: van der Zee opted for the Englishman John Charnaud and the Dutchman William Enslie, while Wissing chose the Englishman Richard Lee and the Dutchman Christiaan

18 NACs, $\mathrm{N}^{\circ} 348$, 'Request van A: Wissing tot antwoord aan van der Zee \& Comp tot reclamatie van sijn saldo bij Clement van Sanen en van der Zee', Izmir, 30/o3/1771.

19 NACs, $\mathrm{N}^{\circ} 348$, 'Versoek van de huijsvrouwe van de heer Wissing tot het doen van een protest teegens de heer van der Zee', Izmir, 13/04/1771.

$20 \quad$ NACs, $\mathrm{N}^{\circ} 348$, 'Replica Nicolas van der Zee weegens een arrest op 205 brooden spianten en het vragen van borgtocht voor de persoon van Arnoldus Wissing', Izmir, 13/04/1771. The end of the document contains a paragraph added by the consul in which he mentions that the sequester was made orally - which might be the reason no documents pertaining to the sequester can be found in the case file.

21 NACs, $\mathrm{N}^{\circ} 348$, 'Replica Nicolas van der Zee', Izmir, 13/04/1771.

22 NACs, $\mathrm{N}^{\circ} 348$, 'Antwoord van Arnoldus Wissing op vragen cautie', Izmir, 17/04/1771. 
Rodemuller. ${ }^{23}$ All the men were either merchants or persons experienced in trade and the commercial practices of Izmir. ${ }^{24}$ As was common when arbitration was used, both parties agreed not to appeal the decision, on penalty of 3 ,ooo lion dollars should they come back on that agreement. ${ }^{25}$ The inclusion of a high penalty demonstrates the vulnerability of arbitration in an environment in which litigants had more than one court they could go to. The capitulations suggested that European traders could resort to an Ottoman court, even for a dispute with a fellow countryman. ${ }^{26}$

The arbitrators reached a decision in October - very late for such a solution. It was decided that Wissing needed to pay 593 lion dollars to Clement, van Sanen, van der Zee \& $\mathrm{C}^{\circ}$ as the outstanding balance of the current account between them, taking everything into account. Additionally, if the partnership wanted Wissing to take the oath declaring the sale of the pewter had occurred exactly as registered in the books, he would be obliged to do so. ${ }^{27}$ Wissing answered that he could prove the sale had occurred exactly as he had registered it in the books by showing it in the handwriting of the buyer, who had passed away. In dramatic fashion, he added he believed that that evidence would be sufficient in front of the whole world. ${ }^{28} \mathrm{He}$ did not oppose the decision in which he was condemned to pay but needed more time than the three days he had been given. When van der Zee made his claim, he had ended Wissing's employment - for which he needed six months according to the contract - leaving him without much money. Wissing had some personal troubles as well and hoped a longer period of time would be granted to him. ${ }^{29}$ He was given three months to pay, with his wife Constanzia standing as a security on behalf of her husband. The last document pertaining to the case was an act confirming the deposit in the Dutch chancery of a jewel with set diamonds

23 NACs, $\mathrm{N}^{\circ} 348$ 'Nader replicq van van der Zee tot versoek der executie van de transport der spianten in questie', Izmir, 27/04/1771; and NACs, $\mathrm{N}^{\circ} 348$, 'Acte van cautie van Hagi Georgi voor de persoon van Arnoldus Wissing', o1/05/1771.

24 NACS, $\mathrm{N}^{\circ} 348$, 'Compromis aengaende de differentie van Clement van Sanen van der Zee \& Co en Arnoldus Wissing', Izmir, o6/o5/1771.

25 Ibid.

26 See p. 89 .

27 NACs, $\mathrm{N}^{\circ} 348$, 'Copije der arbitraire sententie in de differentie van Wissing met van der Zee', Izmir, o1/10/1771.

28 NACs, $\mathrm{N}^{\circ} 348$, 'Antwoord Arnoldus Wissing op d'intimatie der sententie van d'arbitter in differentie met Clement van Sanen van der Zee', Izmir, ol/10/1771. A month later, he took the oath about the pewter. NACs, $\mathrm{N}^{\circ} 348$, 'Acte der eed van Arnoldus Wissing wegens de 205 spianten in questie met Clement van Sanen van der Zee', Izmir, 05/11/1771. Ibid. 
belonging to Constanzia Wissing. ${ }^{30}$ As there was no more follow-up, Wissing probably paid before the due date of January 1772 .

The type of dispute between Wissing and his principals was relatively easy to adjudicate in the sense that it concerned two Dutch parties, both residing in Izmir. The evidence that was used was related to the business relationship between Wissing and the firm that had employed him - correspondence, current accounts and a contract. The only evidence added to the case beyond those business documents, besides the replies and counter-replies by both parties, was the witness statement issued by Wissing's peers and the registration of the oath that he had been asked to take in order to prove that a sale he had made was indeed made exactly in the way he had registered it in the books. The fact that arbitration was chosen to solve this particular dispute seems not so easy to explain. Arbitration meant that a dispute was put before experts, also referred to as 'good men', or 'neutral men', who would decide the matter in a reasonable manner. Often, courts opted for this solution because the case could be too complicated to be left to judges who might not possess the know-how to adjudicate commercial disputes. A judge was not necessarily up to date with all the customs and habits merchants applied in their dealings with one another.

In principle, parties accepting arbitration also forfeited their right of appeal before another court. It was a particularly handy problem-solving mechanism in disputes between traders because it was cheap and because one could rely on the fact that it was one's peers who were making the decision - ensuring that the dispute was analysed by people who knew the rules of the game according to the merchants' style. According to Amalia Kessler, arbitration served a double purpose. First, it allowed the preservation of personal ties within the larger trading community - early modern trade relied heavily on social ties and mechanisms of trust. ${ }^{31}$ When these were challenged because

$30 \quad$ NACs, $\mathrm{N}^{\circ} 348$, 'Acte van cautie van juffr Wissing voor haer man Arnoldus Wissing voor Lx 593 23/10o tot saldo van reek: met Clement van Sanen van der Zee', Izmir, o8/11/1771; and 'Acte van een gedepositeerd stuk juweel van Arnoldus Wissing', Izmir, 21/11/1771.

31 Kessler, 'Enforcing virtue', p. 84. For an analysis of the concept of 'trust' in seventeenthcentury discourse on commerce and the role trade and trust played in relationships between states, see the chapter on 'The doux commerce and interstate relations. Trust and mistrust in the emerging economic discourse', in Peter Schröder, Trust in early modern international political thought, 1598-1713 (Cambridge, 2017), pp. 199-218. For a more general assessment of the role of trust in the relationship between individual and community, see Hans Blom, 'The meaning of trust: Fides between self-interest and appetitus societatis', in The roots of international law/Les fondements du droit international. Liber amicorum Peter Haggenmacher, eds. Pierre-Marie Dupuy and Vincent Chetail (Leiden and Boston, 2013), pp. 39-58. 
of a dispute, it could harm the larger sociocultural tissue that bound traders together and allowed them to conduct long-lasting and mutually beneficial trade. Arbitration was a way the community itself, through peers, could solve its own disputes - the idea being that a solution would be mutually agreeable as it was not put upon the litigants from a higher judge or some higher legal rules. It is perhaps the purest expression of merchants' style, regulating a dispute and thereby keeping a whole community together. This corresponds to the second function fulfilled by arbitration according to Kessler, which was narrowing the distance between decision-makers and litigants. ${ }^{32}$

Generally speaking, those adjudicating commercial disputes could not be expected to know all the traders involved in them. The recourse to arbitration by peer experts allowed for adjudication by men who were personally acquainted with the litigants, enlarging the latter's trust in the decision but also making sure the parties would be better understood. Personal acquaintances might get better information to base their decision on. Amalia Kessler has pointed out that the element of intimacy and personal ties were so important that, in the case of French merchant courts, arbitration in rural villages was often executed by the village priest. In this case, his task was not simply to decide upon a resolution but to gather information and hear witnesses. ${ }^{33}$

In the context of the Dutch consular court, the choice to subject a dispute to arbitrators was made by the consul and assessors, but it had to be accepted by the litigating parties, who also needed to promise they would not appeal - that would render the whole choice to arbitrate a dispute obsolete. Both parties could appoint an equal number of arbitrators, and at times, the court chose an additional one to ensure that a majority of votes between arbitrators was always possible - a choice not taken in the dispute between Wissing and his principals. At first sight, it might seem remarkable that a dispute between Dutch litigants before a Dutch court was decided upon by a mixture of Englishmen and Dutchmen. But the merchants' style was internationally valid, and the nationality of those instructed to analyse whether it was observed or not was less important than the consideration that the merchants' style was followed. It might also have been an accepted custom in order to counterbalance too much intimacy. When a national community abroad as small as the Dutch contingent in Izmir quarrelled with one another - putting social and commercial cohesion at risk - and the solution of the quarrel lay in international merchant custom, it was not bizarre to rely partially on foreign involvement in

$32 \quad$ Kessler, 'Enforcing virtue', p. 84.

33 Ibid. 
the solution-seeking process. It might provide a fresh but yet familiar look at a quarrel.

The claim made by Nicolas van der Zee against Arnoldus Wissing was of a very rare type - fully situated within the Dutch trading community of Izmir - but still, the solution was found in the international merchants' style, and English traders were involved in the arbitration process. By far, most cases were not so easily delineable where the litigants were concerned. Arnoldus Wissing had worked for the firm in which van der Zee was a partner, but most Dutch traders established in Izmir were not involved in trade with one another. They were independent and entered into business relationships with Ottoman traders and merchants in the Dutch Republic. They entered into legal disputes with members of both groups.

\subsection{A Failed Attempt at Arbitration}

As seen above, merchants often first tried to settle their disputes amicably. In the early seventeenth century, Dutch consuls had received specific instructions to ask litigants to first attempt friendly settlement through arbitration. This option could also be taken when one of the litigants was abroad, and the consular archives of Izmir contain an example of this, although the arbitration process failed in this case. The dispute in question arose between the firm of de Vogel \& Zoon in Amsterdam and the firm of Clement, van Sanen, van der Zee \& $\mathrm{C}^{\circ}$ in Izmir. For the de Vogel firm, the first step was the choice of a power of attorney able to defend their legal interests before the Dutch consular court in Izmir. ${ }^{34}$ The choice of who to give legal power of attorney to was easy, as he had a son, Thomas Junior, who lived in Izmir. The dispute was brought before the Dutch consul in Izmir in 1764 and included a claim on several outstanding debts. According to Thomas de Vogel Junior in Izmir, the total sum concerned was 1,922 lion dollars and 29 aspers. ${ }^{35}$ In his claim, de Vogel explained that this included four different amounts. The first, 118:99 lion dollars, came from an agio of $10 \%$ demanded by Clement, van Sanen, van der Zee \& $\mathrm{C}^{\circ}$ on a purchase on behalf of Thomas de Vogel \& Zoon in Amsterdam of fifteen bales of cotton. ${ }^{36}$

\footnotetext{
34 For the use of powers of attorney, see pp. 16o-162.

35 The consulted sources always noted such sums in the following notation: 1,922:29 lion dollars. Future references to similar sums will be written down in the same manner.

$36 \quad$ NACs, $\mathrm{N}^{\circ} 333$ ('Documenten van de proces tusschen Clement van Sanen van der Zee \& $\mathrm{C}^{\circ}$ \& Th:s de Vogel over een parthij tabak \&a begonnen 1764 eijndigt 11 febr 1765 '), 'Repliek van Th:s de Vogel aan Clement en vansanen raakende de in kwestie zynde schaade der tabak verbrande cattoene \& kwade schulden \& ra', Izmir, 12/10/1764. The agio was the difference between two parallel domestic currencies, i.e., bank money and currency, and reflected an exchange price between the two. See Pit Dehing, Geld in Amsterdam. Wisselbank en wisselkoersen, 1650-1725 (Hilversum, 2012), pp. 108-130.
} 
Thomas de Vogel considered this percentage to be outrageous, particularly as it had only been brought into account seven months after all documents for the cotton transaction had been sent. De Vogel felt that no 'commissioning agent should be able to do business that way.' ${ }^{37}$

A second, larger sum stemmed from damage to a shipment of tobacco that had been on board the Agatha, which was sailing from Salonika to Livorno but had suffered shipwreck near the island of Ponza near the Italian coast. ${ }^{38}$ The damage amounted to 1,200:50 lion dollars, and de Vogel objected to the conclusion of the transaction that had led to the shipment of the tobacco in the first place. ${ }^{39}$ Apparently, two Ottoman traders, Hagi Emir Mustafa and 'Ali Aga, had delivered the tobacco to representatives of Clement, van Sanen, van der Zee $\& \mathrm{C}^{\circ}$ in Salonika in order to settle accounts with Thomas de Vogel \& Zoon in Amsterdam. De Vogel claimed that his principals in Amsterdam had no interest in tobacco, particularly as Clement, van Sanen, van der Zee \& $\mathrm{C}^{\circ}$ had not originally mentioned this in their letters on the matter to de Vogel but had only referred to the debt being repaid. Additionally, Clement and his partners had agreed to the shipment of the tobacco without telling de Vogel and had not insured it, thus failing in their obligations as agents for the commission of de Vogel. They should never have 'subjected the interest of their friend to the sea without properly informing them, ${ }^{40}$ Van Sanen had offered to arrange matters with an insurer, but only for one-third of the value, and according to Thomas Junior such practices went against all merchants' style. The two other sums were 18:50 lion dollars for what de Vogel considered to be excessive postage expenses and a general outstanding balance of $584: 30$ lion dollars. ${ }^{41}$

When arbitration was suggested to solve this dispute, both parties accepted to subject themselves to the judgment of neutral merchants. Each party was allowed to appoint one. Thomas de Vogel Junior chose Daniel Hopker, a business correspondent of his father, while Pieter van Sanen nominated Jacob de

37 NACs, $\mathrm{N}^{\circ} 333$, 'Repliek van Th:s de Vogel aan Clement en vansanen', Izmir, 12/10/1764, '[...] directien welke geen commissionair kan nog mag houden nog practiseeren'.

38 The trial files contain a twenty-two-page declaration made in Italian at the Chamber of Commerce in Livorno on this event. NACs, $\mathrm{N}^{\circ} 333$, 'Zeeverklaaring en manifest, attest: van het keyss: schip de agatha galeij cap:t Christofer Romolj op Ponsa', Livorno, 21/o9/1762. There is some confusion in the documents as to whether the sum related to this event amounted to 1,250:50 lion dollars or 1,200:50 lion dollars, but only the latter makes the entire calculation correct. NACs, $\mathrm{N}^{\circ} 333$, 'Repliek van Th:s de Vogel aan Clement en vansanen', Izmir, 12/10/1764.

40 Ibid., ‘[...] op geenerlij wijse vermoogen eenig intrest huner vriend ter zee te geeven sonder het behoorlijk advys ter regter tijd [...]'. Ibid. 
Vogel (from Rotterdam; he was not related to Thomas de Vogel). The arbitrators met at Hopker's house and investigated the accounts, but the procedure ended abruptly, according to van Sanen because de Vogel did not want to accept arbitration after all, but according to de Vogel because van Sanen had brought in an additional claim about seven bales of burned cotton. ${ }^{42}$ The cotton had been in the hands of van Sanen but was destined for de Vogel in Amsterdam when a fire had damaged it. Originally, van Sanen had not wanted to charge de Vogel for the merchandise, as he believed himself to be responsible, but the outcome of another trial held the same year, in which van Sanen had acted on behalf of an Amsterdam firm that demanded compensation for damaged goods while they were in the hands of an agent, made him change his mind. The outcome of that case was that the agent could not be held responsible for damage to goods that were not his own. A crucial piece of evidence in that case was a declaration signed by various merchants with different nationalities in which they agreed to the commercial principle that an agent was not responsible for goods commissioned by a principal. As long as the agent had acted in accordance with his principal's instructions, and the cause of the damage was beyond the agent's responsibility, he could not be held accountable. ${ }^{43}$ Van Sanen had lost that case, and he seemed to be determined to not be on the paying end twice. In his counterclaim, he made an explicit reference to the declaration issued by the merchants in March 1764 on behalf of his legal opponent at the time. ${ }^{44}$ Van Sanen, who must have been in possession of a copy of the declaration, must have felt he had the merchants' style on his side this time. He justified his manoeuvre by stating that he only found out about his lack of responsibility later, because of the other trial, adding that he was happy to continue arbitration, but as the number of Dutch merchants was small and de Vogel refused to continue with Hopker and Jacob de Vogel, van Sanen proposed to look for arbitrators that were part of another trading nation. ${ }^{45}$

For de Vogel, his opponent's action was unheard of, going against that same merchants' style, because according to 'all rights and laws', an account that was approved by the involved traders and subsequently closed could not be

42 NACs, $\mathrm{N}^{\circ} 333$, 'Attestatie voor dheer Pieter van Saanen, aangaande de geteekende compromis in de differentie met dh Th: de Vogel', Izmir, 15/o9/1764; NACs, $\mathrm{N}^{\circ} 333$, 'Antwoord van den heer van sanen aen dh: Th: de Vogel Junior weeg: eenige pretentie voor dh: Th: de Vogel \& zoon d'Amsterdam', Izmir, [o9/10/1764]; and NACs, $\mathrm{N}^{\circ} 333$, 'Repliek van Th:s de Vogel aan Clement en vansanen', Izmir, 12/10/1764.

43 See pp. $162-189$.

44 NACs, $\mathrm{N}^{\circ} 333$, 'Antwoord van den heer van sanen aen dh: Th: de Vogel Junior', Izmir, [og/ $10 / 1764]$.

Ibid. 
reopened to make new claims on it. ${ }^{46}$ This was commercial custom that, according to de Vogel, Clement, van Sanen, van der Zee \& $\mathrm{C}^{\circ}$ would know about. De Vogel insisted he could not go into an arbitration process with van Sanen any longer, because the latter had 'formulated very unjust and unfounded claims against my principals, that have nothing to do with the case. ${ }^{47}$ De Vogel's refusal effectively ended the attempt at arbitration, and the case was brought before the Dutch consular court in Izmir, where de Vogel filed his claim of 1,922:29 lion dollars on behalf of his father and brother. ${ }^{48}$

Van Sanen, taking the defence on behalf of his partnership, had come up with a different calculation. He dismissed the problem of the agio and argued that de Vogel should know that the agio commonly calculated by the merchants in Izmir was not the same as the one in 'any Christian land', and although the defendant accepted that there were different ways of calculating the agio in Izmir, the end result was the same, the way he had done it was simply a little bit more advantageous for the commissioning agent. ${ }^{49} \mathrm{He}$ had a point, and the quarrel about the agio might be explained by the fact that de Vogel was used to a lower agio in Amsterdam - Pit Dehing has shown that, while it fluctuated, it was on average $4.23 \%$ during the eighteenth century, while Elena Frangakis-Syrett mentions agio rates in Izmir that did indeed reach $10 \%$ in 1761 and $1762 .{ }^{50}$

Perhaps, van Sanen argued, it was not always completely possible to follow merchant custom as it was applied in the United Provinces, as this would cause damage to friends in Izmir - by which he meant that if Thomas de Vogel applied agio on transactions in Izmir in the Dutch manner, it was his friend and agent van Sanen who would be disadvantaged. On the tobacco, van Sanen felt his former firm had done its best to recuperate the money owed to de Vogel by his Ottoman debtors in Salonika and concluded by stating that it was

$46 \quad$ NACs, $\mathrm{N}^{\circ} 333$, 'Repliek van Th:s de Vogel aan Clement en vansanen', Izmir, 12/10/1764, '[...] in alle regten $\mathrm{x}$ wetten $[\ldots]$ '.

47 Ibid., '[...] kan niet met van Sanen in arbitragie treden, mag ook niet, aangezien hij zeer onrechtvaardige $\mathrm{x}$ ongefundeerde pretentien tegen mijn principalen formuleert die met de zaak niks te make hebben'.

48 NACs, $\mathrm{N}^{\circ} 333$, 'Rekwest van dh Thomas de Vogel Junior teegens de heeren Clement vansanen vander zee \& $\mathrm{C}^{\circ}$, Izmir, 26/o9/1764.

49 NACs, $\mathrm{N}^{\circ} 333$, 'Dupliek van dh van sanen op de Repliek van dheer deVogel gedagteekend 12 8bo', Izmir, 31/10/1764, '[...] nergens in't Christenrijck [...]'.

$5^{\circ}$ For other years no information was given. Frangakis-Syrett, The commerce of Smyrna, pp. 200-201; see also Dehing, Geld in Amsterdam, p. 116. For early modern agio rates in Amsterdam, see J.G. van Dillen, 'Bloeitijd der Amsterdamse wisselbank 1687-1781', in Mensen en achtergronden, ed. J.G. van Dillen (Groningen, 1964), pp. 4O3-404. 
completely unreasonable that a commissioner should pay for 'damage caused by the Almighty', to goods that were not his own. ${ }^{51}$

In his counterclaim, van Sanen expressed the opinion that the firm in Amsterdam owed him money instead of the other way around. ${ }^{52} \mathrm{He}$ did not argue about the 584:30 lion dollars in the outstanding balance but added an amount of 86o:28 lion dollars that he claimed de Vogel owed his firm. This sum consisted of debts to de Vogel of 360:28 lion dollars from Hagi Emir Mustafa and Salonali Mahmud Baraka and 5oo lion dollars from Joseph de Bartolomeo, a merchant from Volos in Greece. These had been covered by obligations that Clement, van Sanen, van der Zee \& $\mathrm{C}^{\circ}$ had already settled in their accounts with Thomas de Vogel \& Zoon in Amsterdam but that still needed to be paid. Thomas Junior wrote that van Sanen's claim had been made too late, and it was 'highly obscure and doubtful, going against all merchants' style.53 Furthermore, de Bartolomeo was a French protégé who had recently visited Izmir. At that time, van Sanen could have requested litigation at the French consular court, but he had failed to do so. ${ }^{54}$ Unsurprisingly, van Sanen disagreed and stated that de Bartolomeo had acted as Swedish vice-consul in Volos, so it was impossible to put him under arrest. Van Sanen added that he preferred to do business with traders with conscience, who were looking after the interests of their friends as well as after their own interests, rather than dealing with merchants such as the father and son de Vogel, who 'use books of jurists and consult lawyers in order to follow the law, but at the same time they only looked at their own interest, and pushed that as far as possible, without consulting their conscience., 55

Van Sanen's juxtaposition of the letter of the law versus the respect for reciprocity and mutual interest is very revealing. Amalia Kessler has argued that merchant courts were referring to Christian virtue in the battle of good and evil fought out in court, and mentioning 'conscience' is evidence of a similar discourse here, but there is another reason behind it as well. ${ }^{56}$ Van Sanen's

$51 \quad$ NACs, $\mathrm{N}^{\circ} 333$, 'Replicq van dhr Clement \& van Sanen in de differentie met den heer Th: de Vogel Junior', Izmir, 03/12/1764, '[...] schade door de allerhoogste [...]'.

52 This sort of reversal of who owed who was quite common in this type of case. NACs, $\mathrm{N}^{\circ} 333$, 'Antwoord van den heer van sanen aen dh: Th: de Vogel Junior', Izmir, [o9/10/1764]. NACs, $\mathrm{N}^{\circ} 333$, 'Repliek van Th:s de Vogel aan Clement en vansanen', Izmir, 12/10/1764, '[...] ten uitersten duister $\mathrm{x}$ twijfelachtig, strijdende tegens alle coopmansstijl [...]'.

54 Ibid.

$55 \quad$ NACs, $\mathrm{N}^{\circ} 333$, 'Dupliek van dh van sanen op de Repliek van dheer deVogel gedagteekend 12 8bo', Izmir, 31/10/1764, '[...] cooplieden die zig met regt geleerde boeken $\mathrm{x}$ advocaten consulteeren om de wetten te voldoen, $\mathrm{x}$ verders haar eijgen intrest door omweegen zoo ver pousseeren als maar kunnen, sonder haar gemoet te consulteeren'. 
argument was that the letter of the law was less important than the mutual pursuit of interest, resulting in reciprocity, one of the cornerstones of the merchants' style and a mechanism on which most of early modern trade relied. ${ }^{57}$ Even if the agio had not been calculated strictly according to Dutch law, the importance of mutual interest and the fact that the commercial world of Izmir rendered it impossible to respect Dutch law fully made that little infraction perfectly reasonable and equitable within the context of commercial custom. Taking care of one's friends was more important than adhering to the letter of the law. This is one of the few cases in which one of the parties made a legal argument out of a discrepancy between the law in the United Provinces and commercial custom as it was applied in the specific intercultural context of Izmir, where things worked slightly differently than in Amsterdam or Rotterdam: 'no merchant of any nation can agitate a trader here and direct all of his affairs according the merchants' style and laws of Holland or other countries in Europe, principally as one has to deal with persons of the land [Ottoman Empire]'.58 This shows that, while the merchants' style was internationally applicable, it was also subject to interpretation in a local context. This made the role of foreign traders in the same city, as arbitrator or expert, more important than the role of certain national laws that had been issued far away.

The difference in commercial custom and adjudication in a context of interaction with Ottoman merchants was an important and tangible one, something that all traders in Izmir understood. ${ }^{59}$ But these differences were never absolute, nor were they evidence that Ottomans or other non-Europeans were not well acquainted with the European way of doing trade - perhaps the merchants' style cannot be labelled as a specifically European way of doing trade. In a case that opposed a Dutch merchant to an Ottoman Muslim named Mehmed Araboğlu, the consul addressed an Ottoman official on Ouckama's behalf and wrote to him that 'you know perfectly the merchants' style, for having treated many affairs' ${ }^{\prime 0}$ The merchants' style was thus invoked as some

57 See pp. 173-181 for a more in-depth discussion of reciprocity.

$58 \quad$ NACS, $\mathrm{N}^{\circ} 333$, 'Replicq van dhr Clement \& van Sanen in de differentie met den heer Th: de Vogel Junior', Izmir, o3/12/1764, '[...] geen coopman van wat natie in staat is om een coopman hier te ageeren $\mathrm{x}$ alle zijn zaken te kunnen dirigeeren volgens den coopmansstijl en wetten van Holland of andre landen in Europa, $\mathrm{x}$ principaal zoo men met lieden van $\mathrm{t}$ land te doen heeft [...]'.

$59 \quad$ See chapter 5 .

6o NACs, $\mathrm{N}^{\circ} 332$ ('Brieven wegens de zaak tusschen Arab Ogloe \& Ouckama'), 'Copije der brief int Turks geschreven aen Kútschuk Aga door de heer consul weegens d'affairen van de heer Ouckama \& $C^{\circ}$ na Sanderlj [Çandarlı near Izmir]', Izmir, 11/o9/1765, ‘[...] ed voi, cognoscendo, perfettamente il stile mercantile pr aver trattato molti affari [...]'. For the case itself, see pp. $319^{-323}$. 
sort of generally agreed upon way of doing things amongst merchants but still could be subjected to varieties according to time and place, suggesting a commercial pragmatism that written law could not offer. Litigation based upon summary procedure and the merchants' style was better equipped to deal with relatively new situations, such as the development of intercultural trade in eighteenth-century Izmir.

After arbitration failed, the dispute between Thomas de Vogel Junior and Pieter van Sanen turned into a discussion of the merchants' style, and the consul decided to demand the advice of three neutral merchants, two of whom had been the original arbitrators in this case, Daniel Hopker and Jacob de Vogel, while the third, Daniel Fremeaux, was one of the most important Dutch traders. ${ }^{61}$ Their opinion was that the agio could be charged, the open account with de Bartolomeo was indeed de Vogel's responsibility and van Sanen was allowed to ask a brokerage fee of $5 \%$ for the transaction in Salonika. On the other hand, Clement, van Sanen, van der Zee \& $\mathrm{C}^{\circ}$ did have to pay for the postage that had been disputed as well as for the burned cotton, while the damaged tobacco could not be used in settling the debts owed to de Vogel, meaning the damage was to be disputed between van Sanen and the merchants in Salonika he had gotten it from. ${ }^{62}$ The consul and assessors agreed with all these elements, which led to a verdict confirming the suggestions of the three neutral merchants. As both parties were partially at fault, they were each condemned to pay half of the trial's expenses. ${ }^{63}$ Both parties accepted, and no appeal was made, although it must have frustrated van Sanen, as he had now lost two cases dealing with burned cotton, even though he was plaintiff in one and defendant in the other. A dispute between parties did not necessarily mean that they would stop trading altogether. In September 1765, Thomas de Vogel wrote to his son to not do business with Philippe Clement any longer, because he had received the monopoly in Prussian trade with the Levant, which made him a traitor to the national cause. No mention was made of this trial or of any other legal or commercial disagreement between them. ${ }^{64}$

$61 \quad$ NACs, $\mathrm{N}^{\circ} 333$, 'Rapport van dheeren gecommitteerden in de proces tusschen dheeren van Sanen Th:s de Vogel Jr', Izmir, 04/01/1765.

62 Ibid.

63 NACs, $\mathrm{N}^{\circ} 333$, 'Sententie in de differentie van Clement \& van Sanen \& Th: de Vogel Junior', Izmir, $15 / 01 / 1765$.

64 For the Prussian Royal Levant Company, see pp. 209-213. 


\section{The Mother of Levantine Trade Quarrels: Disputing Commission} Trade

\subsection{The Principal-Agent Problem}

Dutch Levant trade was commission trade, and most Dutch merchants living in Izmir acted as agents on behalf of traders in the United Provinces. In this sense, they were competitors of one another, all striving to obtain new commissions. In order to stay in the picture of firms in the Dutch Republic, the merchants in Izmir cultivated lengthy business correspondences. ${ }^{65}$ These often began with a request made by a principal to conduct a test transaction, or by an offer sent out by aspiring commissioning agents. The international trading community relied on a web of business correspondences, and one of the important characteristics was the reciprocity of services that were offered or sold through these letters. It was not uncommon that the services of certain merchants were recommended by mutual correspondents to other traders in need of a new business contact. In 1762, the firm of Jean Biolley in Verviers, in the Bishopric of Liège, addressed Thomas de Vogel \& Zoon in Amsterdam because he hoped to obtain some information from his correspondent on the best way to establish a trade in sheets with the Levant. De Vogel answered him that Biolley was welcome to trade in his own name but that it was common for traders from Liège to send their sheets first to the United Provinces, where they would be packed as Dutch sheets. These were then sent to the Levant under de Vogel's name, who charged a commission fee on the service. A partnership between de Vogel and Biolley, as the latter had suggested, was impossible, and if Biolley did not want to make use of de Vogel's services, the latter was happy to provide the names of some friends who worked for him on commission. In Izmir, these friends consisted of three firms: David van Lennep, Enslie \& $\mathrm{C}^{\circ}$;

65 For the importance of business correspondence in the establishment of durable commercial relationships, see Aslanian, From the Indian Ocean; Vanneste, Global trade; and Trivellato, The familiarity of strangers. Aware of the importance of business correspondence, early modern merchants had access to business manuals that came to include instructions on letter-writing. Early examples are Gabriel Meurier, Formulaire de missives, obligations, lettres de change, d'asseurances (Antwerp, 1558); Matthias Kramer, Il segretario di banco (Nürnberg, 1693); and Giovanni Domenico Peri, Il negoziante (Venice, 1638); see also essays in Roger Chartier, Alain Boureau, and Cécile Dauphin, eds., Correspondence: Models of letter-writing from the Middle Ages to the nineteenth century (Princeton, 1997); and Francisco Bethencourt and Florike Egmond, Correspondence and cultural exchange in Europe, 1400-1700, vol. 3 of Cultural exchange in early modern Europe (Cambridge, 2007). For the more technical aspects of early modern letter-writing, see James Daybell, The material letter in early modern England. Manuscript letters and the culture and practices of letter-writing, 1512-1635 (Basingstoke, 2012). 
Clement \& van Sanen; and Fremeaux \& Hopker. De Vogel added that the firm had other correspondents in Izmir, but those three were the most important ones, and their services had been good. ${ }^{6}$

Merchants always had to be careful to cultivate their correspondences; when the firm of Thomas de Vogel \& Zoon sent some thread samples to the firm of Cauw in Leiden in 1757, the latter just sent them back, insulted by the fact that de Vogel had already sent similar samples to other firms in Leiden. ${ }^{67}$ The cornerstones of a commercial friendship, expressed through a steady, regular and long-lasting correspondence, were reciprocity and the regard for mutual interests. ${ }^{68}$ While reciprocity implies an idea of equality, it does not discard the possibility of finding mutual satisfaction in a relationship between a principal trader and an agent: first, because agent and principal could be partners in some transactions, and second, because roles could be reversed; for certain transactions, the principal in the United Provinces could become an agent for the agent-turned-principal in Izmir. It was exactly this sort of flexibility of roles that guaranteed reciprocity in early modern international trade. Avner Greif discussed reciprocity in information exchange between traders as a manner to avoid 'free riding'. In a world in which most merchants took on both the role of principal and agent, free riding was equally problematic and was solved through reciprocity. ${ }^{69}$

Not all initiatives to start up a business relationship were rejected. If a first sample was successfully sold, long-lasting relationships could develop. Shipments of samples between the United Provinces and the Levant were accompanied by negotiations on terms of sale in the accompanying letters. When they joined forces in 1759, Dirk Knipping and Pieter Ouckama immediately sent out letters of introduction in which they offered their services to merchants in Amsterdam, Haarlem, Zaandam, Rotterdam and Leiden, as well as Aken, Verviers, Liège, Aix-en-Provence and London. They informed potential business contacts that they had established a company together, with the permission of 'their blood relatives and their principals. ${ }^{70}$

66 Heeringa and Nanninga, Bronnen tot de geschiedenis, 4: pp. 476-477, de Vogel to Jean Biolley Jr., Amsterdam, 10/12/1762.

67 CAA/ADV, $\mathrm{N}^{\circ} 85$ ('Stukken betreffende de pretentie der compagnie op Missir di Eghia te Smirna'), Letter Cauw \& $C^{\circ}$ to Thomas de Vogel \& Zoon, Leiden, 10/o3/1757.

68 Vanneste, Global trade, pp. 81-84.

69 Avner Greif, 'Contract enforceability and economic institutions in early trade: The Maghribi traders' coalition', The American economic review, 83:3 (1993): p. 529.

70 NACs, $\mathrm{N}^{\circ} 490$, Knipping \& Ouckama to Jan Bulte, Izmir, o3/o9/1759, '[...] onder volkomen goetvindinge \& toestemminge onser hoog g'achte bloetverwanten \& principalen [...]'. 
If one of these potential contacts was interested, he sent small consignments of various goods to Izmir to test the market and the commercial abilities of the potential commissioning agents there. Knipping \& Ouckama quickly sold nails belonging to Olof Jolles to Greek shopkeepers, some coffee and cochineal belonging to the Amsterdam trader Vasker Bake to several Jewish shopkeepers and thimbles coming from Rotterdam to Greeks. They also received sheets, linens, paper and pepper from Aron Joseph de Pinto, a member of a wealthy Sephardic family in Amsterdam, and guns, staple items regularly sold by them on behalf of others. ${ }^{71}$ At the end of September, they confirmed to Floris Crol in Amsterdam that they had received three boxes of guns and that they would try to sell them as if they were their own, although there were many weapons in the city, thereby limiting the possibilities. ${ }^{72}$ Knipping already had experience selling weapons on commission for traders in Holland, as the firm of Thomas de Vogel \& Zoon of Amsterdam sent several consignments of guns to the firm of David van Lennep, Knipping \& Enslie in Izmir. In 1756, for instance, the firm was involved in the sale of 2,00o pairs of pistols and eight boxes of flintlocks belonging to Thomas de Vogel \& Zoon to Greek, Jewish and 'Turkish' merchants. These 'Turkish' merchants were Muslims, traders and shopkeepers with names such as Hagi Moussa, Brussali Soffia and Cheutajalj Hagi Soluman. ${ }^{73}$ The firm also took care of de Vogel's textiles and sold them in Izmir and Salonika. ${ }^{74}$ While these transactions were conducted on the basis of commission, de Vogel also dealt with non-Dutch merchant firms, such as the Jewish house of Chaves and Fernandes Dias, with whom he was involved as a partner, sending them textiles that were sold by them on condition of an equal sharing of the profits. ${ }^{75}$ It is not so surprising that it was the de Vogel firm that had managed to branch out directly beyond the Dutch trading community, as they had a family member present in Izmir who was more likely to be trusted and who could set up such partnerships in person, without resorting to intermediaries, and it was practices like these that led to a decline in the Dutch merchants' share in the Dutch Levant trade.

One of the most interesting introductory letters the new firm of Knipping \& Ouckama sent out went to Herman van Coopstad (1708-1772). Van Coopstad was an alderman in Rotterdam at the time and had been one of the directors

$71 \quad$ NACs, $N^{\circ} 49$ o, Knipping \& Ouckama to Floris Crol, Izmir, 24/og/1759.

72 Ibid.

73 CAA/ADV, $\mathrm{N}^{\circ} 76$ ('Factuurboek Thomas de Vogel \& Zoon', $1756-1765$ ), f ${ }^{\circ} 13 \mathrm{r}$ and fo $18 \mathrm{r}$.

74 Ibid., entries on $\mathrm{f}^{\circ} 13 \mathrm{r}, 14,18,48$, to name a few examples.

75 Ibid., $\mathrm{f}^{\circ} 15$, for instance, shows the sale of a parcel of cloth to Jusuf Scufi Kapostolaki by Chaves \& Fernandes Dias, with an equal division of the profits. 
of the local Directorate of Levant Trade. He had commercial interests the Levant since the 1730 s but had gained most of his fortune and notoriety as a slave trader. The Dutch West India Company (WIC) had lost its monopoly on the slave trade in 1730, and van Coopstad's partnership with the husband of his niece was one of the private firms that jumped in. ${ }^{76}$ When Knipping \& Ouckama wrote to him, they wrote to a prominent man. By 15 September 1759, Knipping \& Ouckama had sold 119 pairs of pistols in a joint account with Herman van Coopstad \& $\mathrm{C}^{\circ} .{ }^{77}$ Two weeks later, they announced further sales of pistols but expressed their regret that because of the captains bringing so many guns, selling them at almost any price, the prices they had obtained were not very good. Additionally, they had lost part of the shipment of weapons because of an encounter with an English ship, and the remainder of that shipment had been damaged. The chancellor of the Dutch consulate in Izmir had issued a certificate confirming the state of van Coopstad's shipment, so satisfaction could be obtained from the insurers. Knipping \& Ouckama were aware that such misfortunes, even if they were not their own fault, could hinder the potentially promising relationship with a merchant such as van Coopstad, who obtained at least part of his weapons from arms dealers in Liège: 'we have to report to you with sorrow, that it saddens our soul, that our first enterprise with your honourable (for which we have to pay interest to your honourable) is so unhappy, being young merchants, who try to treat our respective friends with all loyal and honest dealings, fearing to lose a good sum of money in this, while we are convinced of your generosity, and we hope with God's help and according to your honourable promises to compensate the damage. ${ }^{78}$ Relations

76 Ineke Teunissen, Herman van Coopstad en Isaac Jacobus Rochussen. Twee Rotterdamse slavenhandelaren in de 18e eeuw (Rotterdam, 1996). The Rotterdam archives possess an archive on van Coopstad and Rochussen and related families, but it does not contain much information on van Coopstad's Levantine operations. For a recent investigation into Rotterdam's role in the slave trade, see Alex van Stipriaan, Rotterdam in slavernij (Amsterdam, 2020); see also Kwame Nimako and Glenn Willemsen, The Dutch Atlantic. Slavery, abolition and emancipation (London, 2011).

77 NACS, $\mathrm{N}^{\circ} 49$ o, Knipping \& Ouckama to Herman van Coopstad, Izmir, 15/og/1759.

78 NACs, $\mathrm{N}^{\circ} 490$, Knipping \& Ouckama to Herman van Coopstad, Izmir, 29/og/1759, '[...] wy moeten u ed met hertgrondig leetweezen melden, dat het ons in de ziel is smertende, onse eerste onderneeminge, met $u$ ed (waarvoor wy aan $u$ ed intrest moeten betaalen) $\mathrm{x}$ jonge cooplieden zyn, die onze respective vrinden met alle trouwe $\mathrm{x}$ eerlyke behandelingen tragten te bedienen, zoo ongelukkig zyn, zynde wy in vreezen hierby een goede somme gelde te zullen laten zitten, dan dewyl wy van u ed genereusiteit overtuygt zyn, zo hoope wy met gods hulp $\mathrm{x}$ volgens $\mathrm{u}$ ed belofften deze schade inderwaarts te doen winnen $[\ldots]$. 
with van Coopstad, and through him with merchants in Liège, continued but became very problematic later on. ${ }^{79}$

While Knipping \& Ouckama wanted to provide their services to as many firms as possible, van Coopstad was equally interested in relying on several intermediaries who would try to get the best deals for him. This was not only a matter of spreading the risk, it was also a way of testing the competence of different trading houses and of empirically observing which firms would be able to obtain the best prices. As Cauw's reply to de Vogel has shown, this betting on multiple horses could create malcontent. The problem was not so much the practice per se but rather dishonesty or inequality. So, in 1759, Herman van Coopstad not only agreed to send merchandise to Izmir, but he was also conducting business with the Fernandes firm in Istanbul. Knipping \& Ouckama had been informed that the Fernandes firm had merchandise ready to ship to van Coopstad and that the latter was sending two cases of textiles to Istanbul. This disturbed the young merchant house in Izmir, because they felt that an oral agreement had been made to send one case to Izmir, to be sold on a fifty-fifty partnership basis between Herman van Coopstad and Knipping \& Ouckama. They stated that everyone was interested in van Coopstad's commission and that this way of favouring the Fernandes firm was not acceptable. They insisted that van Coopstad had to send one case to Izmir, after which they could show him the commercial advantages they could provide. Van Coopstad's actions, the young partners in Izmir felt, were 'no merchants' style, no sir'. ${ }^{0}$ It is of crucial importance that the merchants themselves used this term to label commercial behaviour, inside as well as outside of court. The legal relevance of the concept meant that behaviour such as van Coopstad's could lead to a legal claim on the part of Knipping \& Ouckama.

It seems that a legal claim was often the final step in a longer process of solution-seeking. ${ }^{81}$ In the first instance, remarks from peers about breaking commercial custom were similar to threats to sue - it was meant as an incentive to set a wrongdoing right. Traders discussed their problems through their established business correspondence, as the example of a discussion between two major firms involved in Levant trade shows. The Amsterdam-based firm of Thomas de Vogel \& Zoon was involved in a variety of business operations with the partnership between David van Lennep and William Enslie in Izmir.

79 See pp. 223-250.

8o NACS, $\mathrm{N}^{\circ} 490$, Knipping \& Ouckama to Herman van Coopstad, Izmir, o1/11/1759, ‘[...] neen myn heer, zulks is geen Coopmans styl [...]'.

81 And disputes over the ownership of consigned goods were perhaps the most common type of disputes. See van den Boogert, The capitulations, pp. 220-224. 
Thomas de Vogel was not only active in the Levant trade, with a son acting as his agent in Izmir, but also in import trade with South America as well as the pepper trade through the Dutch East India Company. ${ }^{82}$ David van Lennep (1712-1797) was the most important trader in the Dutch business community in Izmir. ${ }^{83}$ Van Lennep had arrived in the Levant to work for the firm of Muyssart and de la Fontaine in Istanbul before establishing his own firm in Izmir. In 1758, he married Anne Marie Leystar, the young daughter of a partner in another Dutch firm that was active in Istanbul and Ankara. Two of his daughters married English traders. One married the naturalised Swiss Isaac Morier, member of the Levant Company, who was to become the company's consul-general in Istanbul in $1806 .{ }^{84}$ Another daughter married Jacques de Hochepied, son of Consul Daniel Jean de Hochepied and his successor as consul in Izmir, while one of Daniel Jean's daughters married Jacob van Lennep, the son of David van Lennep. Another of David van Lennep's sons married a daughter of the later Dutch treasurer in Izmir. ${ }^{85}$

In 1762 Thomas de Vogel \& Zoon purchased the Vrouwe Catharina, with the intention to make journeys to the Levant. De Vogel \& Zoon acted as bookkeeper and possessed one-eighth of the ship. Van Lennep \& Enslie also held a share of one-eighth. ${ }^{86}$ The latter's firm was crucial for using the ship in commercial voyages because out of the fifteen shareholders, it was the only firm that resided outside the United Provinces in Izmir and was very valuable in procuring cargos for the return voyages. When the Vrouwe Catharina arrived back home from a journey to the Levant in October 1765, part of the cargo of currants was found to have gone bad. ${ }^{87}$ De Vogel wrote to van Lennep \& Enslie that he thought that they surely had not seen it, as they never would

82 For the de Vogel firm, see Hakkı Kadı, Ottoman and Dutch merchants, pp. 183-197.

83 A painting of him and his family is preserved in the Rijksmuseum. See figure 6.

84 Two years earlier, he had also been appointed as ambassador, and both functions were unified in 18o6. Wood, Levant Company, p. 184.

85 For a genealogy of the family branch in Izmir, see http://www.levantineheritage.com/pdf/ The_Van_Lennep_Genealogy_Smyrna_Branch.pdf. Further information can be found in Mariëlle Hageman, Amsterdam in de wereld. Sporen van Nederlandse gedeelde verleden (Amsterdam, 2017); and Henry McKenzie Johnston, Ottoman and Persian odysseys: James Morier, creator of 'Hajji Baba of Ispahan', and his brothers (London and New York, 1998).

86 Heeringa and Nanninga, Bronnen tot de geschiedenis, 3: pp. 503-504, 'De Levantvaarder "De Vrouwe Catharina"', Amsterdam, 30/10/1762.

87 The story of the currants is narrated through a selection of letter fragments sent by Thomas de Vogel \& Zoon (labelled by Heeringa and Nanninga as de Vogel \& $\mathrm{C}^{\circ}$ ) to van Lennep \& Enslie that are found in Heeringa and Nanninga, Bronnen tot de geschiedenis, 4: pp. 1194-1196 (o7/10-05/11/1765), pp. 1204-1206 (07/03/1766), and pp. 1210-1213 (22/o8/ 1766). 
have shipped rotten currants that also had been very poorly packed. The other shareholders were angry, and in order to limit the financial damage, de Vogel had already written to Amsterdam's aldermen asking them to nominate three neutral persons to estimate the condition and value of the currants, which would immediately be sold at a loss at a public auction. ${ }^{88}$ The event was seen as potentially harmful to de Vogel, who, in Amsterdam, had been responsible for the trip, and to van Lennep, who had obtained the cargo. Several letters were sent back and forth between the two firms, with van Lennep \& Enslie reluctant to take responsibility until de Vogel ended the conversation by stating that he had observed van Lennep's desire to continue 'a friendly correspondence', something he also wanted to do, so the firm decided to let the whole affair pass, cancelling any further efforts to pinpoint responsibility. ${ }^{89}$ During the whole conversation about responsibility, the authorities at no moment assumed a role, except for appointing neutral men - probably other merchants - who could determine the value of the cargo. At any given moment, though, de Vogel could have decided to look for a peer in Izmir to provide him with a power of attorney to act on behalf of the ship's shareholders and to take the firm of van Lennep \& Enslie to court.

That he did not do so might be testimony to the importance of keeping van Lennep \& Enslie as friends or to the doubts de Vogel had about a successful outcome. After all, he was also directly involved as the bookkeeper for the vessel. But it is not hard to see that the lack of physical contact between trading partners in international trade could create a multitude of problems. One had to do with the lack of ability to monitor the behaviour of agents or partners far away, a second was the problem of verifying information about markets abroad and a third was how to sue merchants living at a great distance. It was quite common that agents sold products at prices their principals were not happy about. Knipping \& Ouckama wrote to van Coopstad in September 1759 that they were unable to sell some of the weapons he had sent them at a good price because of the competition from captains of a number of ships that had just arrived, who were selling 'à tout prix'.90 A couple of days earlier, they had informed Benjamin and Samuel Symons, Jewish diamond traders in Amsterdam, that they had not sold their diamond rings because the price set by them was too high. ${ }^{91} \mathrm{~A}$ principal who received letters with such remarks

88 Ibid.

89 Heeringa and Nanninga, Bronnen tot de geschiedenis, 4: p. 1210, Letter Thomas de Vogel \& Zoon to David van Lennep \& Enslie, Amsterdam, 22/o8/1766, '[...] vriendelijke correspondentie [...]'.

90 NACS, $\mathrm{N}^{\circ} 49$ o, Knipping \& Ouckama to Herman van Coopstad, Izmir, 29/og/1759.

91 NACS, $\mathrm{N}^{\circ} 49$ o, Knipping \& Ouckama to Benjamin and Samuel Symons, Izmir, 24/og/1759. 
could not automatically know whether they were true, whether the agent was incapable, or if, perhaps, the agent was cheating. Economic historians have labelled this the 'principal-agent problem'.92 This problem could be solved in a number of ways, first of all by relying on the trust-generating mechanisms of credit and reputation to ensure the agent's behaviour would remain in check. Loss of access to credit or damage to personal reputation could be fatal blows for any trader. A second option was to maintain different correspondences in any given place and to make regular enquiries about colleagues and their economic circumstances. In spite of all measures taken to prevent problems, commercial transactions unavoidably did go wrong at times, and merchants did take each other to court. In the case of both litigants being Dutch, the court would be Dutch too. The problem was not so much 'national' competence but distance. In disputes between principals in the United Provinces and agents in Izmir or elsewhere in the Ottoman Empire, the competent court was that of the defendant according to the principle of forum rei. If a Dutch agent in Izmir was accused of wrongdoing, he had to defend himself at the Dutch consular court.

Generally, merchants tended not to travel to settle a dispute in court, particularly when it was far away. In cases brought before the consular court in Izmir, this meant the principal in the United Provinces, or elsewhere in Europe, would have a notary write a declaration stating his place of residence, and in it, he would give a merchant abroad the power of attorney. This was an old form of legal contract, made up before a notary, in which legal agency was transferred from a principal to an agent. ${ }^{93} \mathrm{~A}$ notarial deed granting a fellow trader power of attorney was a common legal instrument in international trade, as with the expansion of commercial activities, since traders could not always attend to their affairs abroad in person. Several of the Dutch traders in Izmir acted as

92 Lamikiz, Trade and trust, p. 9. For additional literature on trust in a medieval and early modern context, see also Ana Sofia Ribeiro, Early modern trading networks in Europe. Cooperation and the case of Simon Ruiz (Abingdon, 2016); David Hancock, 'A w world of business to do": William Freeman and the foundations of England's commercial empire, 1645-1707', William and Mary quarterly, 57:1 (2000): pp. 3-34; Dahl, Trade, trust; Ann M. Carlos and Stephen Nicholas, 'Agency problems in the early chartered companies: The case of the Hudson's Bay Company', Journal of economic history, 50:4 (1990): pp. 853-875; and Avner Greif, 'Reputation and coalitions in medieval trade: Evidence on the Maghribi traders', Journal of economic history, 49:4 (1989): pp. 857-882. For the importance of social and kinship ties in commercial relations of trust, see the classic text by Yoram BenPorath, 'The F-connection: Families, friends, and firms and the organization of exchange', Population and development review, 6:1 (1980): pp. 1-30.

Fusaro, Political economies, pp. 234-235; and van Gelder, Trading places, p. 169. 


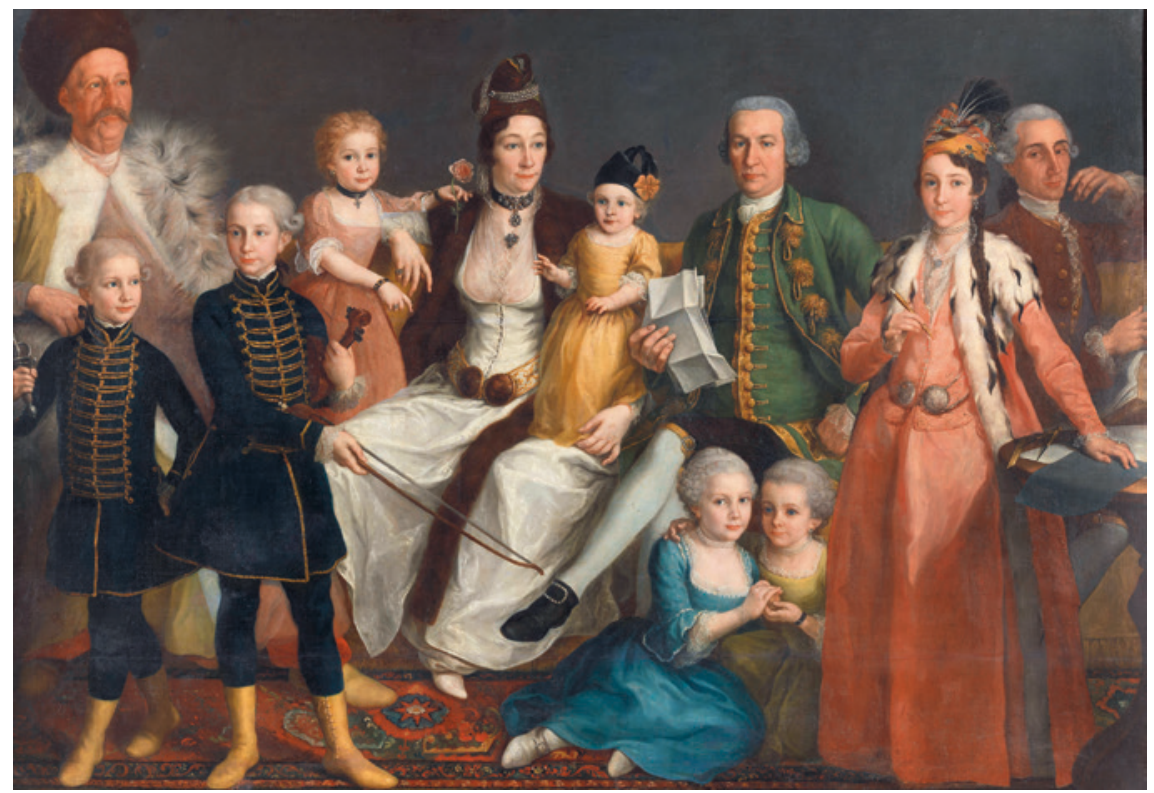

FIGURE 6 David George van Lennep (1712-1797), senior merchant of the Dutch factory at Smyrna (Izmir) with his wife and children, attributed to Antoine de Favray, 1769-1771

FROM THE COLLECTION OF THE RIJKSMUSEUM, AMSTERDAM

plaintiffs on behalf of traders elsewhere. ${ }^{94}$ This meant that a firm that could be competing with the defendant for the same commercial opportunities was now called upon to defend the interests of a principal far away in the United Provinces. The granting of a power of attorney required trust, and the legal agent was expected to defend the principal's interests in the best way possible, just like a commercial agent was supposed to look after the best interests of the principal in business matters. While it can be argued that commercial agents were chosen based on a mixture of established reputation, credit and perhaps a sample sale, not all of these criteria could always be used to assess a legal agent. While commercial agents had a direct financial incentive to do their job well, through the commission fee, a similar direct financial incentive did not exist for legal agents. ${ }^{95}$ Of course, there were positive incentives, as a principal satisfied with his representation in court could become a more important

94 Powers of attorney were not limited to litigation. Arnoldus Wissing received one to make commercial decisions on behalf of his principals. See p. 140.

95 I have found no evidence suggesting that legal agents were paid by those who had given them power of attorney. 
business partner for the agent. It is hard to find clear reasoning behind a particular choice for a legal representative, also because existing source material is not always very informative on the different choices that traders made in this regard. But if a merchant had business interests in a place, and thus a number of correspondents he dealt with structurally, it seems not that big of a step to draft a power of attorney, have it notarised and send it abroad. Acting on someone's behalf in court must have been part of the reciprocal services traders rendered one another - refusing it might result in a loss of reputation, and a trader never knew when he could use a legal agent himself. Reciprocity, again, was key.

\subsection{Commission Trade Gone Wrong}

Not all disputes were resolved through arbitration. The criteria the judges adjudicating commercial disputes used to refer litigants to arbitration were not clearly defined; Kessler pointed out how it was related to the complexity of a case, as well as to considerations linked to maintaining cohesion within the merchant community. ${ }^{96}$ Sometimes, arbitration was not considered, and the quarrel turned immediately into a trial. When Pieter Ouckama ended his partnership with Dirk Knipping, he started to take on commissions from the United Provinces in his own name. One of the merchant firms that had been working with him was the Amsterdam-based partnership of Wijnants \& Cramer. Eventually, they felt that Ouckama had not served them well, and they had a power of attorney drafted in Amsterdam by notary Salomon Dorper on 19 November 1763, in which they provided Clement, van Sanen, van der Zee \& $\mathrm{C}^{\circ}$ with the power of attorney to close all accounts Wijnants \& Cramer still had with Ouckama \& $\mathrm{C}^{\circ}$ in Izmir. ${ }^{97}$ In case Ouckama was unwilling to close accounts or tried to slow down any final settlement, Philippe Clement and his partners had the authority to take him to court, 'rightfully following local style', and to request an advantageous sentence and appeal against a disadvantageous one..$^{98}$ If necessary, they were also allowed to demand sequesters on monies in Ouckama's hands in Wijnants \& Cramer's name. ${ }^{99}$ The reference to 'local style' is very revealing. It confirms that there was not one merchants' style that could be identified as a lex mercatoria, but rather the simultaneous development of converging usages, shared customs and the common use of

\footnotetext{
$96 \quad$ Kessler, 'Enforcing virtue'.

97 CAA, $\mathrm{N}^{\circ} 5{ }^{\circ} 75$ ('Archief der notarissen standplaats Amsterdam'), Salomon Dorper, $\mathrm{N}^{\circ} 10812$ ('Minuutacten', o1/11/1763-31/12/1763), 'Procuratie', Amsterdam, 19/11/1763.

98 Ibid., ‘[...] in regten na style locaal [...]'.

99 Ibid.
} 
summary procedure - a development that had local variations, as well as differing local relationships to legal institutions. Emily Kadens has argued that such convergence was brought about by an increasing tendency to think about the law from the perspective of Roman law, which led to efforts 'to use definitions and procedure to try to turn custom into something more recognizable to them [trained lawyers] as law. In the process, they changed and colonized traditional conceptions of custom.'100 To what extent the latter can be said to apply to early modern commercial adjudication is unclear, but it is true that in Dutch legislative efforts at regulating it, there was an exclusive focus on procedure - custom was left alone.

The remark in the procuration is exactly along the lines of van Sanen's reasoning in his dispute with the de Vogel firm, when he argued that one had to follow local rules more than habits that developed far away in the United Provinces. ${ }^{101}$ The first action of Clement's firm was to go to Ouckama's house, where they demanded to see all accounts related to business with Wijnants \& Cramer. Ouckama showed one current account that Clement found insufficient, so he wrote the consul to demand that Ouckama be forced to produce all the relevant business documents. ${ }^{102}$ The consul ordered his chancellor to inform Ouckama of the request and to order him to provide the 'true and rightful current account' within seventy-two hours. ${ }^{103}$ At this point, the dispute was not very concrete yet - in a way, the consular court was mediating between a principal demanding the closure of current accounts because of a general dissatisfaction with the agent's services and an agent who seemed reluctant to provide immediate clarity on his business dealings. Clement made his request in January 1764, and it was far from a strange one, as it was common for business documents to be used in trials. A series of written replies and counter-replies between the litigants followed until the consul and his assessors reached a verdict in May 1764. The case was of average length, containing twenty-five documents, although some of them were long narratives. It was

\footnotetext{
100 Emily Kadens, 'Convergence and the colonization of custom in pre-modern Europe', in Comparative legal history, eds. O. Moréteau, A. Masferrer, and K.A. Modéer (Cheltenham, 2019), p. 168.

101 See p. 151.

102 NACs, $\mathrm{N}^{\circ} 330$ ('Stukken raakende de proces van Clement van Sanen van der Zee \& $\mathrm{C}^{\circ}$ als procurateuren vand heeren Wynants \& Cramer d'Amsterdam teegens de heer Ouckama \& $\mathrm{C}^{\circ}$ alhier weegen $36 \mathrm{~b}$ verongelukte catt: in de brand van 6 aug l.l. van 17 jan: tot 21 juny anno 1764'), 'Request van Clement van Sanen van der Zee \& Comp tot versoek van reek: courant aen Ouckama te vraagen weeg Wynants \& Cramer', Izmir, 16/o1/1764.

103 Ibid., ‘[...] de egte en regte reek: courant [...]'.
} 
resolved within five months, which was quite long, as the dispute quickly narrowed down to a single transaction.

When Ouckama handed over more detailed information to the court three days later as was required, he pointed out that on most points there was no disagreement. In fact, Ouckama reminded the court that he had already made an official declaration about his services to Wijnants \& Cramer earlier, and his business books had already been subjected to an official viewing by the chancellor and several witnesses. ${ }^{104}$ Apparently, Wijnants \& Cramer had made an attempt to settle matters earlier, but no documents have survived of this, which might very well have been because it had been an amicable attempt to close accounts between two parties. The single transaction that was disputed was about thirty-six bales of cotton that had been purchased by Ouckama on behalf of Wijnants \& Cramer in Amsterdam, for which he received a commission fee. Unfortunately, these bales were stacked in a Dutch warehouse on the night between 5 and 6 August 1763, when a fire ravaged parts of Izmir and destroyed almost all of the Dutch housing. ${ }^{105}$ According to the monthly Gentleman's and London Magazine, the 'most dreadful fire [...] in less than 24 hours reduced to ashes the whole quarter occupied by the Christians. The qadi would by no means be prevailed upon to endeavour to stop the fury of the flames, as few of the Turks were affected by the disaster'.106

The quarrel between Wijnants \& Cramer as plaintiff and Ouckama, who had worked for them on commission, as defendant turned into one of the most typical commercial disputes - responsibility for damages to goods that were part of commission trade. The central issue was to what extent an agent in Izmir could be held accountable for what happened to goods he had been trading on behalf of a principal in the Dutch Republic, or elsewhere in Europe - particularly considering the damage was due to an uncontrollable event. Ouckama had charged Wijnants \& Cramer for the bales of cotton damaged or lost in the fire, but the latter felt that they should not assume financial responsibility for the cotton, as they argued it was not (yet) theirs. Wijnants \& Cramer were of the opinion that Ouckama \& $\mathrm{C}^{\circ}$ had not acted as honest merchants

104 NACS, $\mathrm{N}^{\circ} 330$, 'Antwoord van Ouckama \& Comp weegens de pretentie van Clement van Sanen \& $\mathrm{C}^{\circ}$ voor dhr Wijnants \& Cramer d'Amsterdam', Izmir, 19/o1/1764.

105 It seems only Dirk Knipping's house was spared, as he lived in the Armenian neighbourhood (see figure 4). After the fire, the Dutch consul was forced to rent a house in the same neighbourhood, even though he still owned an out-of-town residence in Sediköy. Heeringa and Nanninga, Bronnen tot de geschiedenis, 3: pp. 483-484, Consul Daniel Jean de Hochepied to the States General, Izmir, 24/08/1763.

106 Gentleman's and London magazine: Or, monthly chronologer (Dublin, 1763), 32: p. 561. 
during the fire, an accusation that could severely damage the latter's reputation. Wanting 'to show the whole world' that he was indeed an honest merchant, Ouckama was now more willing to show his books to the judge and to confirm their veracity under oath. ${ }^{107} \mathrm{He}$ would also allow the chancellor, in the presence of witnesses, to make copies and draw extracts from all the posts in the books that concerned business with Wijnants \& Cramer, but this had to be paid for by Clement, van Sanen, van der Zee \& $\mathrm{C}^{\circ}$. He would not provide the copies himself, as he felt that he was not obliged to do so legally, and his behaviour was evidence in itself that 'no suspicion of fraud remained'. Furthermore, 'he had other things to do'.108 Ouckama clearly put the burden of proof on his opponent, who, as plaintiffs, indeed needed to demonstrate that something had gone wrong.

Clement, van Sanen, van der Zee \& $\mathrm{C}^{\circ}$ replied they were indeed satisfied about most of the transactions but not about the thirty-six bales of cotton that had been bought for Wijnants \& Cramer and that Ouckama had marked in his books as burned by fire. These thirty-six had come out of a total purchase of sixty bales, made in two transactions; forty at first, of which sixteen had been damaged, and an additional twenty, all of which were damaged. The remaining twenty-four had been shipped to the United Provinces on board the ship of skipper Severus Zeegenberg. Clement, van Sanen, van der Zee \& $\mathrm{C}^{\circ}$ did not deny that the cotton had indeed been bought on behalf of Wijnants \& Cramer, but they pointed to the fact that the Amsterdam-based traders had instructed Ouckama to ship it immediately, at the first opportunity. Ouckama, they continued, had been offered a shipping opportunity, and he refused to accept it. Both van Sanen and van der Zee had personally asked Ouckama to provide them with some return cargo for the Maria Dorothea, which was to sail back to the United Provinces with skipper Jacob Hilkes, who had been witness to these meetings. These demands had been made well before the fire occurred, and Ouckama ignored them, a negligence that made him responsible for the damage to the cotton. An additional argument to place the financial burden of the cotton on Ouckama was that the current account between Ouckama and Wijnants \& Cramer showed that, at the time of the fire, Ouckama did not have enough of Wijnants \& Cramer's money in his accounts to buy the cotton on their behalf with their money. ${ }^{109}$

107 NACS, $\mathrm{N}^{\circ} 330$, 'Antwoord van Ouckama \& Comp', Izmir, 19/01/1764, ‘[...] aan de geheele wereld te toonen $[\ldots]$ '.

108 Ibid., '[...] geen suspitie van fraude overblyft $\mathrm{x}$ omdat wy ook wel wat anders te doen hebben $[\ldots]$ '.

109 NACs, $\mathrm{N}^{\circ} 330$, 'Replicq van dhn Clement, van Sanen van der Zee \& Comp op het antwoord van Ouck \& $\mathrm{C}^{\circ}$ weegens Wijnants \& Cramer', Izmir, 24/o1/1764. 
The core of the argument was that Ouckama had not acted as a good agent in several ways. His poor handling of Wijnants \& Cramer's affairs made him liable for the damage done to the cotton. Philippe Clement continued his reply to Ouckama's claims by stating that he was most surprised about Ouckama's persisting refusal to show all documents related to his business with Wijnants \& Cramer. His firm was entitled to see them as they held power of attorney from Wijnants \& Cramer, which was an official legal instrument. Second, Ouckama had stated his desire to 'show the whole world they [Ouckama \& $\mathrm{C}^{\circ}$ ] were honest merchants', and Clement argued this was the perfect occasion to do so. ${ }^{110}$ Clement's firm, a partnership of honest people, would have taken it. Clement rebuffed Ouckama's claim that he had used the term 'suspicion of fraud' in his first request on 16 January but stated that he simply followed merchants' style (coopmansstyl), to be judged and satisfied according to justice and equity. ${ }^{111}$ The connection Clement made between the merchants' style and equity is important, as it is the idea of equity as deriving from principles of reason and natural law that made the merchants' style such a logical and acceptable foundation for merchants to settles their commercial disputes. ${ }^{112}$ For Clement, it was a matter of following commercial custom, and the outcome of a procedure doing so could, in his eyes, only lead to an equitable verdict that would naturally be accepted by all parties involved.

Clement's reply suggests that merchants considered litigation as more than the ultimate resort to disputes. Amalia Kessler has stressed the social function of arbitration, but litigation in general fulfilled an important social role within the international merchant community. Traders thought of the court as a place where a litigant's reputation was subject to 'peer-review'. The assessors, who were Dutch traders acting as assistant-judges, were not only there to ensure the adherence of the court to merchant custom but also to form an opinion on reputation, an opinion that might have had a bigger impact than the reputational judgment that took place in traders' business correspondences.

The court was a place where the (international) habits of merchants were subjected to national jurisdiction. It was perhaps the only institution that aimed to sanction the behaviour of traders that stood with one foot in the merchant community, where rules and habits were often international, informal and noncodified, and with another foot in the world of laws issued or recognised by a government. With regards to trade disputes, laws were not applied to settle a dispute but to provide the legal context in which the dispute could

\footnotetext{
110 Ibid., '[... van aan de geheelen wereldt te toonen zy eerlyke lieden zyn [...]'.

111 Ibid., '[...] geene minsten gewagh van suspitie van fraudes gemaakt [...]'.

112 See pp. 128 and $132-133$.
} 
be settled. In other words, informal conflict-regulating solutions that derived from peer-review judgment could only be expected to carry sufficient weight to be accepted by all involved if such judgment came from a formal governmentsanctioned institution that relied on procedure. It explains why great lengths were taken by the authorities to make sure that the Dutch consular court of Izmir was legitimate vis-à-vis the legal system in the United Provinces, the legal system in the Ottoman Empire and the legal systems under which merchants of other European trading nations found themselves.

\subsection{Whose Responsibility Is It?}

Ouckama's behaviour as an agent for others was under scrutiny here, and his liability in the matter of the damaged cotton was to be determined by the merchants' style. It was the court's task to assess the evidence in that light. To build their case, Clement and his partners insisted on having full access to all accounts related to the cotton. They felt it was crucial to find out whether the cotton had been bought with money that was unrelated to Wijnants \& Cramer or whether the purchase had been financed with profits on goods sold on behalf of Wijnants \& Cramer. The answer to this question would be crucial in determining responsibility for the damage, because the cotton was a return cargo that was theoretically paid for from the profits of the sales of Wijnants \& Cramer's exports to Izmir. If it was proven that Ouckama had not used the latter's money, then Wijnants \& Cramer could not be expected to take any financial responsibility for the cotton, as it would not be theirs. Secondly, Clement knew that Ouckama had not observed his principals' instruction to ship as fast as possible. He was given the option to load the cargo on board the Maria Dorothea of skipper Jacob Hilkes, in which the firm of Clement, van Sanen, van der Zee \& $\mathrm{C}^{\circ}$ was a shareholder. Pieter van Sanen, Nicolas van der Zee and Jacob Hilkes had personally informed Ouckama of that option, but he chose not to take it. ${ }^{113}$ Later, Ouckama shipped the twenty-four bales that had not been damaged on the Vrouwe Berendina of skipper Severus Zeegenberg, and Clement knew that it had not been the first Dutch ship to leave Izmir for

113 NACs, $\mathrm{N}^{\circ} 330$, 'Replicq van dhn Clement, van Sanen van der Zee \& Comp op het antwoord van ouck \& $C^{\circ}$, Izmir, 24/o1/1764. From the documents it is clear that the firm of Clement, van Sanen, van der Zee \& $\mathrm{C}^{\circ}$ was part-owner of Hilkes' ship, or at least responsible for logistics in Izmir. In 176o, Pieter van Sanen and Jacob Hilkes appeared before the qadi in Izmir, assisted by a dragoman for the Dutch nation and the consul, to be heard in a case in which the Maria Dorothea was allegedly used to transport money and jewels that belonged to a Tunisian prince from Naples to Izmir, and further to Istanbul. They denied any involvement. See Verzameling van geheime brieven, 13: n.p., Consul Daniel Jean de Hochepied to an unknown addressee, Izmir, 29/11/176o. 
the United Provinces after the fire, again showing Ouckama's incapability to follow the orders he had been given. ${ }^{114}$

Lastly, Clement and his partners dismissed Ouckama's willingness to take a statement under oath and his proposal to obtain an official declaration of the truthfulness of his books from the chancellor, as they felt they could get sufficient information from the business papers. The oath was an important means of evidence, and if Ouckama was willing to take it, it could be a problem for Clement, but as the business documents contained enough evidence, the plaintiff did not see the necessity of taking one. ${ }^{115}$ After reading Clement's statement, Consul de Hochepied ordered his chancellor to inform Ouckama and demand a reply from him within seventy-two hours. The reply came a bit earlier this time - two days later. He argued that he had not acted against the order for the prompt return of the shipment and claimed he had been unable to load the cotton on board a ship bound for the Dutch Republic immediately after having received the merchandise. ${ }^{116}$ To demonstrate that he had been working as fast as he could, Ouckama referred to his correspondence with an uncle in Amsterdam, Sirp Ouckama. Because Wijnants \& Cramer had instructed Ouckama to not bother them with every detail, he decided to keep his uncle up to date with all that was happening. That way, Pieter Ouckama had to write fewer letters to Wijnants \& Cramer, saving postage.

At some point, Pieter Ouckama had asked his uncle to inform Wijnants \& Cramer that he was busy procuring forty bales of cotton for a return cargo on their behalf. After the cargo was bought, he started to look for ships, but according to Ouckama, it was not possible to use the Maria Dorothea. Skipper Jacob Hilkes was supposed to leave by mid-July, when the cotton had not been secured yet. Ouckama tried to ship other merchandise on Hilkes' ship, but disagreements over the freight charges had brought an end to that. In the end, Hilkes had indeed stayed in port longer than foreseen, planning to sail on 6 August. But according to Ouckama, he had not postponed his departure to wait on the cotton but on the arrival of the caravan that brought Angora yarn. There would have been no place for Wijnants \& Cramer's forty bales of cotton, nor for the twenty additional bales that Ouckama received on the afternoon of the fifth, which were also destined for Wijnants \& Cramer. Ouckama had therefore started to negotiate with another captain, Adriaan Jansz Leuning, and Philippe

114 NACS, $\mathrm{N}^{\circ} 33$, 'Replicq van dhn Clement, van Sanen van der Zee \& Comp op het antwoord van Ouck \& $\mathrm{C}^{\circ}$, Izmir, 24/o1/1764.

115 For the establishment of the oath as legal proof in the Levantine context, see p. 134.

116 NACs, ${ }^{\circ} 330$, 'Replicq van Ouckama \& $\mathrm{C}^{\circ}$ aan Clement van Sanen, van der Zee \& $\mathrm{C}^{\circ}$ weegens Wijnants \& Cramer d'Amstm', Izmir, 26/o1/1764. 
Clement had even promised to come into town on the sixth to assist in these talks. Ouckama could thus not have shipped earlier. ${ }^{117}$

A second argument to dismiss the claim that Hilkes was waiting for a return cargo of cotton was made by recalling certain events that happened the night of the fire. When Ouckama found out what was happening, he asked Pieter van Sanen and Nicolas van der Zee for assistance salvaging some of the cotton. He wanted them to send a sloop from Hilkes' ship, of which they were part-owners, so at least the twenty bales, which had only been received the day before and had not yet been properly stored, could be saved. In spite of their promise to help, Clement and van der Zee clearly 'preferred to break their word, leave a compatriot to his own devices and help a Frenchman instead'.118 Ouckama had no choice but to throw the cotton in the water, hoping to save them from being fully consumed by the fire. Clement referring to the cotton as 'supposedly burned and perished' was insulting considering Ouckama's efforts, and Ouckama asked Clement to be careful about the words he used, or he would resort to other means. ${ }^{119}$

The question about whose money had financed the purchase of the cotton saddened Ouckama, because Wijnants \& Cramer knew very well that Ouckama could not finance so many bales of cotton with the returns from sales on Wijnants \& Cramer's behalf alone. The fact that he had been willing to use other money was an argument in favour of Ouckama's efforts to buy and ship rapidly. It was a generally known fact that the shopkeepers who bought the goods coming from Europe paid very slowly. Therefore, it would have been impossible to ensure a rapid return cargo by relying exclusively on the profits of the merchandise sold on behalf of Wijnants \& Cramer. If Clement, van Sanen, van der Zee \& $\mathrm{C}^{\circ}$ felt Ouckama could only finance return cargos from the shopkeepers' payments, they had to understand that the consequence was that a return shipment could only be made two years later; three months were needed for buying, shipping and arriving in Izmir, twelve months for selling these goods from the United Provinces and receiving payment, two months for buying return goods and three months for the journey home. At that rate,

117 Ibid. Leuning, a skipper from Rotterdam, must have been one of the first Dutch skippers to leave Izmir after the fire, because he was one of the two skippers who had loaded goods belonging to Consul de Hochepied on board his vessel. Heeringa and Nanninga, Bronnen tot de geschiedenis, 3: pp. 483-484, Consul Daniel Jean de Hochepied to the States General, Izmir, 24/08/1763.

118 NACS, $\mathrm{N}^{\circ} 330$, 'Replicq van Ouckama \& $\mathrm{C}^{\circ}$ aan Clement van Sanen, van der Zee \& $\mathrm{C}^{\circ}$, Izmir, $26 / 01 / 1764$, , $[\ldots]$ het heeft die heeren liever behaagt hun word niet te houden, een nationaal te verlaaten $\mathrm{x}$ een Fransman te helpen [...]'.

119 Ibid., '[...] de zogenaamde verbrande off verongelukte cattoenen [...]'. 
Ouckama would have been long dismissed as agent by Wijnants \& Cramer. In any case, if they only wanted their own money spent, they should have instructed Ouckama to do exactly that. ${ }^{120}$

Ouckama was also disappointed by Clement, van Sanen, van der Zee \& C's refusal to have him take the oath. This, he argued, actually gave him the opportunity to commit 'the biggest fraud in the world', because even if he handed over the business papers now, as requested, the truthfulness of their contents would have to be taken for granted. ${ }^{121}$ An oath would have added formal veracity to the business books, clearing Ouckama's name and confirming his honesty. Fully aware of the importance of reputation for merchants, but also of the importance of the oath as a means of evidence, Ouckama felt his adversaries had taken away a possibility for him to clear his name. ${ }^{122}$

This time, the plaintiff's reply took longer than usual - more than ten days. When it finally arrived, it expressed some strong sentiments. Clement and his partners felt that Ouckama had been childish for not choosing a ship for the return cargo, because their friends in Amsterdam - Wijnants \& Cramer - could not have known which ships would leave first from Izmir. ${ }^{123}$ Furthermore, all Ouckama needed to have done was give his word that he would ship his cargo on board the Maria Dorothea, and Clement, van Sanen, van der Zee \& $\mathrm{C}^{\circ}$ would have secured as much cargo space as necessary. To substantiate their point further, they added that their business books showed that they had purchased 130 bales of cotton after discussions with Ouckama about filling the ship, confirming that space had not been the problem. Clement was further disappointed that Ouckama mentioned a discussion on freight charges as the problem. They had promised him there was going to be space on their ship, and a promise, even when only made orally, had a clear and binding value in the merchant community. The discussions on freight charges, 'pertinent lies', were considered by Clement and his partners as an attempt to label them as deceitful. ${ }^{124}$ Clement further complained about using Sirp Ouckama as an intermediary in the communication between Ouckama in Izmir and Wijnants \& Cramer in Amsterdam. It meant that it could not be proven that the bales of cotton Pieter Ouckama referred to in his letters to his uncle had indeed been

\footnotetext{
120 Ibid.

121 Ibid., '[...] de grootste fraude der weereld [...]'.

122 Ibid.

123 NACS, $\mathrm{N}^{\circ} 330$, ' $2{ }^{\mathrm{e}}$ replicq van dhn Clement van Sanen \& $\mathrm{C}^{\circ}$ in de differentie met Ouckama \& $\mathrm{C}^{\circ}$ weegens Wijnants \& Cramer d'Amstm', Izmir, o7/o2/1764. This shows that physical distance could create a particular problem: asymmetric information.

124 Ibid., '[...] impertinente $x$ leugenaghtige expressies [...]'.
} 
purchased for Wijnants \& Cramer, as that was not stated explicitly in the letters. Clement strongly believed that, had the fire not taken place, the cotton might very well have turned out to be Pieter Ouckama's, a severe accusation. In any case, Wijnants \& Cramer were not personally informed by Pieter Ouckama about the cotton purchases, and Clement felt it went against all merchants' style for an agent to anticipate a return purchase without the approval of the principal, particularly cotton, which was not fetching great prices in the United Provinces at the time. ${ }^{125}$

Clement, van Sanen, van der Zee \& $\mathrm{C}^{\circ}$ persisted in their refusal to have Ouckama take the oath or have his business books checked by a public official, as they felt they could rely on witnesses to prove that Ouckama had not followed the orders of his principals, which they deemed as more than sufficient. ${ }^{126}$ This persistence suggests Clement felt that Ouckama's position was stronger. Should he have been allowed to take the oath, it would have been difficult for the plaintiff to convince the court of his wrongdoing. In that sense, the refusal to have another party take the oath was part of the legal discussion about the nature of the case and not a refusal of the legal validity of the oath or public declarations as evidence, rather, to the contrary. An oath was considered such a strong form of evidence that it was not taken lightly.127

Clement also rebuffed the accusation that he had not helped a fellow countryman during the calamity of the fire. He recognised that at two o'clock in the night, van der Zee had gone to Ouckama, who had demanded the assistance of Hilkes' boat. But when both men tried to find Hilkes, they could not, because he had left with van Sanen to help a French trader, Majastre, whose house was on fire and who always had been 'a good friend' to the firm of Clement, van Sanen, van der Zee \& $\mathrm{C}^{\circ} .{ }^{128}$ After helping him out, Majastre returned the favour by sending a French sloop to help salvage goods (belonging to Clement, van Sanen, van der Zee \& $\mathrm{C}^{\circ}$ ), a reciprocal favour that Ouckama would not have been able to provide. So Clement surely would have wanted to help a compatriot rather than a foreigner, but not under these circumstances. They also did not care much for Ouckama's threat to use other means if they did not

\footnotetext{
125 Ibid.

126 Ibid.

127 See also Kessler, 'Enforcing virtue', p. 93, 'Although from the modern perspective it seems extraordinary that the outcome of a lawsuit could turn solely on a litigant's oath, in the world of the Old Regime an oath made to God on penalty of eternal damnation remained a serious matter'.

128 NACS, $\mathrm{N}^{\circ} 33$, ' ${ }^{\mathrm{e}}$ replicq van dhn Clement van Sanen \& $\mathrm{C}^{\circ}$ in de differentie met Ouckama \& $\mathrm{C}^{\circ}$ weegens Wijnants \& Cramer d'Amstm', Izmir, $07 / 02 / 1764$, '[... $]$ een goede vriendt [...]'.
} 
change their vocabulary, a threat that must have been meant to have an impact on their good name, because they replied that there was nothing that could harm their 'honour or reputation.' ${ }^{129}$ In case Ouckama came up with 'follies and nonsense', they would counter with something to silence him. ${ }^{130}$ In a similar manner to the understanding that the international merchants' style was stronger than national law in commercial litigation, the ability for merchants to reciprocate and observe each other's mutual interests was stronger than the loyalty created by sharing a nationality.

The reciprocal threats made by both parties are a reminder of what was at stake in these trials - beyond the financial aspect. Both sides being convinced that they were not to blame for what happened, they resorted to questioning each other's motives and actions, threatening to damage each other's public reputation. The disagreement continued but shifted to an argument about the nature of (commercial) friendship, and Ouckama turned the discussion into an attack on a more personal level. He stated that Clement, van Sanen, van der Zee \& $\mathrm{C}^{\circ}$ had 'so often declared to our Ouckama to be his intimate friend, but orally, never in business correspondence.'131 Ouckama accused the firm of not helping him and that 'friends who are friends out of interest are our enemies, as interest makes many people unreasonable'.132 Ouckama's accusations must have hit hard, and van Sanen felt obliged to write an additional letter the same day his company officially replied to refute Ouckama's characterisation of their friendship. He felt he had no choice but to consider Ouckama's remarks as slander and attributed them to 'his weak mind.'133 He ended the letter by quoting a Latin expression, 'friends who want to sell my onions as lemons are not my friends', suggesting he was rejecting Ouckama's friendship. ${ }^{134}$

To question friendship was to put someone's reputation on the line. It was very important that friendship between two traders was recognised by their peers, as that way it could be evaluated against the standards applied in the international merchant community, not in the least those about reciprocity. A successful friendship demonstrated that friends adhered to the principles

\footnotetext{
129 Ibid., '[...] onse eer off reputatie [...]'.

130 Ibid., '[...] bagatellen off gekheeden [...]'.

131 NACS, $\mathrm{N}^{\circ} 330$, 'Replicq van Ouckama \& $\mathrm{C}^{\circ}$ aan Clement van Sanen, van der Zee \& $\mathrm{C}^{\circ}$ ', Izmir, $26 / 01 / 1764$, '[...] die zo meenegmaal aan onse ouckama mondelings dan nooyt zaakelyk betuygt hebt, zyn intieme vriend te zyn [...]'.

132 Ibid., '[...] vrienden die uyt intrest vrienden zyn, zyn by ons vyanden, want de intrest doet veele menschen buyten de reeden gaan'.

133 Ibid., ‘[...] zijn swakke geest [...]'.

134 Ibid., '[...] vrienden die mijn oijens voor citroenen willen verkoopen mijn vrienden niet zijn [...]' The expression comes from 'selling turnips for lemons'.
} 
of merchant custom, and the cultivation of friends amongst merchants not only enhanced one's reputation, but it also enlarged the network of peers that could testify of such a reputation. This was of crucial importance, as these testimonies were used to obtain new business opportunities, as well as to protect oneself in litigation. It was thus hardly surprising that van Sanen wrote an additional letter.

No friendship could survive without reciprocity. In that sense, van Sanen's choice to help out a French friend who was able to reciprocate, instead of a Dutch national who could not do the same, was fully in line with what could be expected from van Sanen according to the merchants' style. This idea of friendship might strike present-day readers as contradictory, but it was commonplace in the early modern conception of friendship. ${ }^{135}$

\section{$3 \quad$ Friendship on Trial}

3.1

\section{The Bond between Merchants}

The exchange between Pieter van Sanen and Pieter Ouckama arguing over friendship is highly relevant to the notion of a merchants' style. This has to do with the fact that both merchants attached a number of mutual duties to their relationship - related to the expectations on behaviour as inscribed in the merchants' style. A discussion on friendship necessitates a definition of friendship - one that is dependent on the historical context, as there is a great ideal of varying interpretations of what constitutes a friendship even today. A few characteristics that we would consider important today come to mind: the fact that a friend is chosen, instead of given in the way a family is, the fact that there are common interests and the idea that there is a certain intimacy and comfort in the presence of friends. ${ }^{136}$ These elementary notions of friendship can equally be seen as 'cultural stereotypes', and scholars who

\footnotetext{
135 For an elaborate analysis, see Luuc Kooijmans, Vriendschap en de kunst van het overleven in de zeventiende en achttiende eeuw (Amsterdam, 1997). Adam Smith also developed economic ideas on the meaning of commercial friendship, particularly in his Theory of moral sentiments (Edinburgh, 1759). For differing interpretations of his ideas, see Lisa Hill and Peter McCarthy, 'On friendship and necessitudo in Adam Smith', History of the human sciences, 17:4 (2004): pp. 1-16; and Allan Silver, 'Friendship in commercial society: Eighteenth-century social theory and modern sociology', American journal of sociology, 95:6 (1990): pp. 1474-1504.

136 Liz Spencer and Ray Pahl, Rethinking friendship. Hidden solidarities today (Princeton and Oxford, 2006), p. 59 .
} 
look into the meaning of friendship often debate to what extent such characteristics can be taken out of a friendship without it necessarily losing its label. ${ }^{137}$

For our analysis, two things are important to consider. First, the concept of friendship is subject to change depending on the social and historical context. This means that when an early modern trader referred to a colleague as a friend, many people today might assume that they shared more, and more profound, things with one another than their profession. While it is certainly a possibility that van Sanen and Ouckama did share more - after all, they were part of a small community that was the guest in a city that was part of a different social, cultural and religious entity - the Ottoman Empire. The extension of business ties into the world of social ties was certainly a characteristic of commercial friendship during the early modern period - but it was not a necessary condition for us to accept their use of the concept of friendship as genuine. ${ }^{138}$

Second, discussions on elementary aspects of friendship have not led to the idea that there is only one type of friendship. Different types are considered, and often, these are ranked according to how much they relate to some 'ideal' form of friendship that is mostly related to the stereotypes mentioned above. Simpler forms of friendship considered within that scheme could be associates or useful contacts, while the most complex forms of friendship could be soulmates or confidants. ${ }^{139}$ The ranking of types of friendship is old, and has already been promoted by Aristotle, who distinguished between advantagefriendship, pleasure-friendship and virtue-friendship, the latter being the most valuable. ${ }^{140}$ It is further been argued that certain Greek ideas of friendship have persisted for a remarkably long time in western society and were still quite commonplace during the eighteenth century. ${ }^{141}$ In this sense, one could easily consider the commercial friendships under discussion here as

137 Ibid.

138 For more on merchant sociability in the context of generating trust, see Tijl Vanneste, 'Commercial culture and merchant networks: Eighteenth-century diamond traders in global history' (unpublished PhD thesis, European University Institute, 2009), pp. 102103. For the Mediterranean and Ottoman context, see Fusaro, Political economies, pp. 219221; and Quentin van Doosselaere, Commercial agreements and social dynamics in medieval Genoa (Cambridge, 2009).

139 Spencer and Pahl, Rethinking friendship, p. 6o.

140 'Introduction', in Friendship: A history, ed. Barbara Caine (London and New York, 2009), p. x. One of the most persistent Greek notions of friendship was that it was only possible amongst men. Ibid., p. xii.

141 Ibid., p. x. 
advantage-friendships, but this does not mean they were merely driven by utility and self-interest.

For merchants to engage in business with one another, trust was important, as well as a certain degree of predictable behaviour. Such trust and predictability can be relied upon by constructing commercial friendship, which respects the rules of the merchants' style - otherwise, such friendship would not be possible. And one of the most crucial rules was to put mutual interest and reciprocity above self-interest and egoism. Peers were expected to follow this rule, and expectations were a crucial part of friendship. In an interesting analysis, P.E. Digeser has put forward the notion that, in all our discussions on friendship, 'language of duty gets in the way of describing what matters in our friendships. ${ }^{142}$ What he me meant is that, in our analyses, too much focus on the idea that duties and obligations do not mix with true friendships obscures the fact that they are not at all irreconcilable. Part of the answer lies in his notion that, while duty, obligation and self-interest might be part of a friendship, they cannot be explicitly invoked in the language of the friendship. This is inspired by Sarah Lynch's ideas about friendship. Digeser observes that 'in a friendship, one must act as if other aims (such as interest, personal advantage, pleasure) were "transcended" [...] Lynch is trying to capture the idea that we may be driven by duty, but the truth is corrosive of the relationship'.143 It is a very interesting and useful line of thinking, as it would allow us to see the merchants' frequent expression that they adhered to the merchants' style, as well as their sometimes fierce and passionate language when accused of selfinterest, as part of 'performing' a role. The whole cohesion of the merchant community as relying on commercial friendship is to a certain extent based on the way in which all participants are willing to accept that role, which, to a point, is a façade.

This façade was meant to guarantee that merchants always respected reciprocity and adhered to the idea of a mutual pursuit of profit, instead of following their self-interest. Lengthy formulations in business correspondences, mutual favours, letters of recommendation - these are all part of that same façade deemed a necessary support for the way in which merchants were able to interact with one another on a daily basis. Considered in this way, our modern doubts about the sincerity with which eighteenth-century merchants referred to each other as friends vanish, as these doubts were based on wrong assumptions.

\footnotetext{
142 P.E. Digeser, Friendship reconsidered. What it means and how it matters to politics (New York, 2016), p. 64.

143 Ibid., p. 68.
} 
In his monograph on the friendly ties between different families in the seventeenth and eighteenth centuries, Luuc Kooijmans defined friends as the people who can be 'talked to in order to reach certain goals or to solve problems. ${ }^{144}$ This definition seems far removed from our modern notion of friendship, which is essentially interest-free, but Kooijmans successfully argues that we should not anachronistically judge early modern ideas of friendship as purely calculated relationships. The kind of relationship merchants maintained allowed for the pursuit of one's personal gain, but this also included a certain reciprocal privilege, which meant, in trade, the granting of favours and discounts. This kind of friendship required the careful cultivation of relationships, enabling traders to live up to their reputation by demonstrating their reliability. For merchants, there were several ways to do so, most importantly by maintaining a regular business correspondence. ${ }^{145}$

In the eighteenth century, the Scottish thinker David Hume (1711-1776) came up with the paradigm of interested and disinterested commerce. He considered 'interested' trade as modern, based on the idea that man acts out of self-interest. Since a mutually profitable transaction is generally not instantaneous, a convention is adopted to make sure the first receiver gives back. This convention is the explicit promise of looking out for the interests of the other in the future. ${ }^{146}$ The expectation that a favour would be returned was an essential part of the merchants' style and part of the reason why traders could trust one another - they could trust them to adhere to the conventions of the merchants' style. Importantly, the reciprocity that comes from looking out for mutual interests can be rationalised within the framework of self-interest; not keeping one's promise goes against self-interest, since it makes a trader lose his reputation, his credit and thus his long-term possibilities of finding new trading partners. ${ }^{147}$ There also existed an older form, 'disinterested' commerce, in which an exchange was rewarded by gratitude. The first receiver was not formally expected to return the favour.148

For Hume, the interested form of commerce was modern but had not abolished the older form of disinterested commerce that he attached specifically

144 Kooijmans, Vriendschap, p. 327, '[...] degenen die konden worden aangesproken om bepaalde doelen te bereiken of problemen op te lossen'.

145 Ibid., p. 327. For the use of business correspondence to establish friendly ties, see Vanneste, Global trade, pp. 84-88.

146 Pierre Force, Self-interest before Adam Smith: A genealogy of economic science (Cambridge, 2003), pp. 171-174.

147 For a discussion of commercial friendship and trust in the eighteenth-century, see Vanneste, 'Commercial culture', pp. 100-111.

148 Force, Self-interest, pp. 171-174. 
to friendship (that would also come closer to our own view of friendship). But Hume's analysis leaves space for the notion that merchants did not see the reconciliation between (a modified form of) self-interest and friendship as problematic - as long as self-interest was mutually protected. Interested commerce, as Hume defined it, required reciprocity, and reciprocity (or, more generally, the creation of mutual expectations) can be thought of as one of the foundational elements that made early modern international trade possible. In this context, the commercial friendship that merchants referred to in their arguments was connected to the expectation of doing business along the lines of the merchants' style, or along the lines of Hume's interested, modern commerce.

The early modern notion of commercial friendship was important because it was attached to a merchant's reputation. Wijnants \& Cramer probably never set foot in Izmir, nor did they meet Pieter Ouckama in person. But they needed to trust him, which was possible through setting up a business correspondence, but also through recommendations made by third parties. If traders $\mathrm{A}$ and $\mathrm{C}$ were interested in doing business together, person $\mathrm{B}$, a friend in business to both of them, was a necessary intermediary. It was normal for merchants to endorse each other's reputations by writing formal letters of recommendation. The alternative was the collection of information from a series of correspondents about a series of potential business partners. ${ }^{149}$ Ouckama must have come recommended to Wijnants \& Cramer, perhaps through Clement, van Sanen, van der Zee \& $\mathrm{C}^{\circ}$.

Disputes between two traders could have serious repercussions beyond the damage done to the relationship between those two traders. After his dismissal as the partner of David van Lennep and William Enslie, caused by his marriage to a Greek woman, Dirk Knipping travelled to the United Provinces in an attempt to ensure his contacts of his continued friendship and to look for new correspondents. ${ }^{150} \mathrm{He}$ met with Thomas de Vogel Senior at the Amsterdam exchange, but it was a rather frosty encounter. Nevertheless, Knipping was allowed to speak further with de Vogel at his house, but the encounter ended with de Vogel ceasing all business with Knipping, even though he did not want to think of him as an enemy. Knipping felt the marriage and the possible consequences thereof, were a private matter and that van Lennep had treated him

149 In the business archives of the firm of Hope \& $\mathrm{C}^{\circ}$, based in Amsterdam and one of the most successful Dutch firms of the eighteenth century, several books have been preserved containing such information. CAA, $\mathrm{N}^{\circ} 735$ ('Archief Hope \& $\mathrm{C}^{\circ}$ ), $\mathrm{N}^{\circ} \mathrm{s}$ 1404-1407; see also Vanneste, Global trade, p. 89 .

$15^{\circ}$ See pp. 70-71. 
unfairly. De Vogel took van Lennep's side. He expressed his surprise that someone who had received so many advantageous favours from David van Lennep could make himself so unworthy. He also promised van Lennep to ensure that their contacts in the United Provinces would be informed of the true reason of Knipping's ousting, the marriage, as Knipping had been spreading misinformation. De Vogel also told van Lennep that Knipping's behaviour in the United Provinces had been poor, and he should not worry that his credit or honour might suffer as consequence of this change, perhaps even to the contrary. Knipping, it seems, was not held in high esteem by de Vogel's correspondents, with his temper and his tendency to talk a lot, and his behaviour when he was in the United Provinces had made things worse. ${ }^{151}$

In a world in which trust and reputation were important commodities, and in which the private and professional spheres were not so easily delineated, one had to consider carefully how to interact with fellow merchants, and naturally, personal sympathies played a role next to considerations of commercial performance. In 1767 , Thomas de Vogel wrote to his son in Izmir that Pieter van Sanen was offering advantageous terms to firms in the United Provinces, which meant that he would receive a great number of commissions, something that de Vogel was quite happy about. ${ }^{152}$ But when he found out that William Enslie, partner of David van Lennep, planned to consign all his goods to his younger brother in Amsterdam, de Vogel was less happy and advised his son to do business with van Lennep but to ignore Enslie, whose friendship was 'worthless.'153 Some years later, Leonard de Vogel informed his brother Thomas in Izmir that he intended to leave the world of trade but that another brother de Vogel had entered a partnership with the same brother of Enslie in Amsterdam. ${ }^{154}$ Such shifting alliances, sometimes accompanied by hefty language in commercial correspondence, were not at all uncommon in the early modern world of international trade.

The exact relationship between Ouckama and van Sanen, Clement and van der Zee is not clear, but obviously they all knew each other. They lived near

\footnotetext{
151 CAA/ADV, ${ }^{\circ} 36$, pp. $56-58$, Letter Thomas de Vogel \& Zoon to David van Lennep, Amsterdam, 06/o6/1758; and ibid., pp. 175-177, Letter Thomas de Vogel \& Zoon to David van Lennep, Amsterdam, 21/o7/1758. Hakki Kadi wrote that de Vogel even asked his correspondents not to engage in business with Dirk Knipping, Ottoman and Dutch merchants, p. 203.

152 Heeringa and Nanninga, Bronnen tot de geschiedenis, 4: pp. 1229-1230, Thomas de Vogel \& Zoon to Thomas de Vogel Junior, Amsterdam, o6/10/1767.

153 Ibid., p. 1231, Thomas de Vogel \& Zoon to Thomas de Vogel Junior, Amsterdam, 22/12/1767, '[...] niets waard'.

154 Ibid., p. 1261, Leonard de Vogel to Thomas de Vogel Junior, Amsterdam, 23/o4/1771.
} 
one another in the European quarter of Izmir, but no specific references were made in the court documents about any social interactions between them. It was important for the litigants to avoid the blame for the destruction of a hitherto mutually beneficial commercial friendship, which explains the emotional tone of some of the court documents. Reports on certain behaviour in Izmir quickly found their way to traders in the United Provinces by means of business correspondence, and as all Dutch merchants in Izmir lived off commission trade, it was important to not damage one's reputation back home - as it would be difficult to repair from a distance. This explains why van Sanen was so upset to be labelled a 'phony friend' that he felt obliged to address a personal statement to the court in which he countered the accusations against him, in addition to the normal replies that he had sent as partner of the firm that was involved in the lawsuit against Pieter Ouckama \& $\mathrm{C}^{0} .155$ Van Sanen made it very clear that he wanted Ouckama to respond to the question whether he thought it was in his interest to hurt van Sanen's 'honour' ('eer'), which meant, of course, his personal reputation..$^{156}$

Friendship between traders, founded on the notion of reciprocity and maintained through the cultivation of a business correspondence, formed the fabric of the international merchant community. Webs of friendships flourished and declined, and their functioning was not only subjected to the informal judgment of peers within that community but also to formal evaluation in court. Legal challenges to reputation were part and parcel of commercial litigation, and they were always taken seriously, as happened in the litigation between Ouckama and Wijnants \& Cramer. In his personal statement, van Sanen wrote that in his firm, Ouckama was always mentioned with praise, and often, van Sanen was told by his peers that he 'was a sincere friend of Ouckama and even much taken with him.157

It is important that van Sanen specifically mentioned that other merchants had labelled him as such. The possibility of evaluating a commercial friendship in court was an essential feature of the merchants' style, as it allowed for a formal evaluation of the functioning of relationships within the international merchant community on the basis of informal rules. Commercial friendship was part of it and came with expectations attached to it that could be evaluated in court. Perhaps the most important task of the judges at the consular court, which included merchants, was to make an assessment of the behaviour

\footnotetext{
155 NACs, $\mathrm{N}^{\circ} 330$, 'Antwoord van dhr P: van Sanen particulier aan P. Ouckama weegens onderlinge vriendschap', Izmir, o7/o2/1764, '[...] een valse vriend $[\ldots]$ '.

156 Ibid.

157 Ibid., '[...] U is een reghte vriend van Ouckema x selvers heel starck van hem ingenoomen'.
} 
of litigants in relation to what could reasonably be expected from them. If such assessment turned out to be negative, it would be known to colleagues, and the repercussions to one's reputation could be large. Just as van Sanen had been upset for being called a false friend, Ouckama was distressed about Wijnants \& Cramer's insinuations that he and his firm were 'being considered as dishonest people [...] that is the most unfriendly term that one could ever put in public writing'.158

In essence, commercial litigation should be considered as trial by peers on the basis of the merchants' style, which was accepted by the state under whose jurisdiction the particular court adjudicating the matter resided. This acceptance could take a formal form through the absorption of mercantile custom in written-down local law or through the confirmation that a certain court needed to adjudicate on the basis of commercial custom, an instruction explicitly given to the consul of Aleppo in 1613 for instance. ${ }^{159}$ It was a form of legalising merchant custom through jurisdiction and procedure, but not through the codification of law.

In their written exchanges, Ouckama and van Sanen had raised the stakes. A dispute that evolved around financial liability for a cargo of damaged cotton turned into a formal evaluation of commercial friendship. Van Sanen had explicitly mentioned reciprocity, a crucial principle, as the reason behind him assisting the French trader Majastre instead of helping Ouckama. Majastre assisted van Sanen during the fire, but Ouckama could not offer any help. Additionally, van Sanen had already provided Ouckama with several favours. As discussed above, Dutch merchants in Izmir did not engage much in commercial transactions with one another. The reciprocal services they were able to provide to one another were thus not directly related to business transactions between each other but had to do with helping out one's business with third parties - the services consisted of offering credit, introducing one another to new potential correspondents, accepting to put one's name on a particular shipment to avoid taxes and acting as the power of attorney in disputes, etc. ${ }^{160}$

The firm of Clement, van Sanen, van der Zee \& $\mathrm{C}^{\circ}$ not only provided a service to Wijnants \& Cramer by their willingness to act as plaintiff on their behalf in the case against Ouckama, but they also assisted Ouckama in his

158 NACS, $\mathrm{N}^{\circ} 330$, ' 3 e replicq van Ouckama \& Comp weeg Wijnantz \& Cramer', Izmir, 28/o2/ $1764, '[\ldots]$ ons voor oneerlyke lieden te houden [...] dat is de onvriendelykste term die men ooyt in publicque geschriften kan stellen[...]'.

159 See pp. 131-132.

16o A good example of such a service was Arnoldus Wissing's acceptance to act on behalf of Clement, van Sanen, van der Zee \& $C^{\circ}$ in trade. See p. 140. 
operations on behalf of Wijnants \& Cramer. They promised Ouckama cargo space on a ship they were part-owners of. They also aimed to help Ouckama with the shipment of the twenty-four bales of cotton that had not been damaged in the fire. ${ }^{161}$ Clement and his partners accused Ouckama of not obeying his principals' instructions by shipping the undamaged bales on the ship of Severus Zeegenberg, which had not been the first to leave. ${ }^{162}$ While Ouckama agreed that might indeed have been the case, he argued that, at the time, his information was that Zeegenberg would be the first Dutch skipper to leave. He also suggested that Clement, van Sanen, van der Zee \& $\mathrm{C}^{\circ}$ raised this point not to defend the interests of Wijnants \& Cramer but to defend their own. Apparently, Clement and his partners had suggested that Ouckama could load the twenty-four bales of cotton on the Jonge Jacob of skipper Richard Horneer, which was partially owned by Clement, van Sanen, van der Zee \& $C^{\circ} .163$ Ouckama felt they were trying to press him to load on their ship against the interests of his principals. For him, this was not only an unfair interpretation of what had happened, it was also an ungrateful action on their part. Ouckama claimed that many firms in Izmir were able to confirm that, in the past, he often shipped return cargos on behalf of principles in the Dutch Republic on ships in which Clement, van Sanen, van der Zee \& $C^{\circ}$ had a share. While van Sanen defended his actions as services given to Ouckama, the latter thought of them as breaching commercial custom in their lack of consideration for the interests of others: 'friends who are friends out of interest are our enemies'.164 This phrase was perhaps the most important in the whole trial in terms of connecting commercial friendship and expected behaviour with the merchants' style and the role of reciprocity. To fully do justice to the importance of the latter, we need to look at the idea merchants had about the mutual pursuit of profit, a concept rated as more important than self-interest.

161 To resume the situation, Ouckama had purchased sixty bales for Wijnants \& Cramer, of which thirty-six had been damaged (sixteen out of a first purchase of forty, and all twenty of a second purchase). This left twenty-four undamaged bales of cotton that had to be shipped to the United Provinces.

162 NACS, $\mathrm{N}^{\circ} 33$, 'Replicq van dhn Clement, van Sanen van der Zee \& Comp op het antwoord van ouck \& $\mathrm{C}^{\circ}$, Izmir, 24/o1/1764.

163 In 1766, another ship (or the same one under a different name), the Smirniotta, captained by Richard Horneer, commissioned by Clement and loaded by van Sanen, van der Zee $\& \mathrm{C}^{\circ}$ to sail from Izmir to Stettin, was considered an Izmir-based action of the Prussian Royal Levant Company, which stood under the general directorship of Philippe Clement and whose establishment was contested by the Dutch. Heeringa and Nanninga, Bronnen tot de geschiedenis, 4: p. 44; see also pp. 209-213.

164 NACs, $\mathrm{N}^{\circ} 330$, 'Replicq van Ouckama \& $\mathrm{C}^{\circ}$ aan Clement van Sanen, van der Zee \& $\mathrm{C}^{\circ}$ ', Izmir, $26 /$ o1 $/ 1764$, ' $[\ldots]$ vrienden die uyt intrest vrienden zyn, zyn by ons vyanden $[\ldots]$ '. 


\subsection{The Mutual Pursuit of Profit}

Merchants accepted each other's pursuit of profit as long as it took place within the well-established set of rules developed in the merchants' style, which dictated that reciprocity was a key element of any business relationship. Selfinterest at the expense of others was a serious infraction. In 1721, Consul Daniel Jean de Hochepied sent a letter to the States General reporting a fraud committed by a Jewish merchant, who had attempted to sell wax from Marseille to Dutch traders by pretending it was Ottoman wax. This led to a commercial boycott in the form of a battelatie issued by the English, Dutch and Venetian trading nations, who agreed to not conduct any business with the Jewish merchant for three months. In his report, the consul stressed that the trader in question had attempted these 'intrigues' for 'his own particular profit'. ${ }^{65}$ This example is very informative for the scholarly debate on the motives behind economic behaviour. Often, self-interest has been considered the prime motivator for the rational homo economicus. This is subject to debate nowadays, and can be nuanced by contemporaries' views on trade, in which there was hardly any place for self-interest as a respectable motive behind economic action, as well. ${ }^{166}$ For contemporaries, self-interest only had a place in economic activity if it was balanced within a wider context of mutual interests. ${ }^{167}$

Ouckama's accusation of acting out of self-interest was a serious one, potentially very damaging to the reputation of van Sanen and his partners. At first, van Sanen's firm denied that his firm has asked Ouckama to load the cotton on board Horneer's ship. ${ }^{168}$ In a letter van Sanen sent the same day in his own name, however, he did admit that he had tried to convince Ouckama to load merchandise on that ship. Firstly, he wrote that Ouckama often preferred the ships of others to load his return cargo on but that could not be held against him, considering it was a choice he had to make in agreement with his principals in the United Provinces. Secondly, he wrote that he had spoken with Ouckama around the time that the Vrouwe Berendina, Zeegenberg's ship, arrived in Izmir carrying several parcels of cloth that belonged to a partnership between Sirp Ouckama and Abraham Musquetier \& Zoon of Leiden, who

165 Heeringa and Nanninga, Bronnen tot de geschiedenis, 2: pp. 381-383, Consul Daniel Jean de Hochepied to the States General, Izmir, 25/o8/1721, on p. 381, '[...] intrigues [...]' and '[...] om sijn particulire profijt [...]'. For the concept of battelatie, see p. 92.

166 When self-interest was mentioned in cases adjudicated by the Dutch consular court in Izmir, it was always with a negative connotation.

167 Apart from the cases studied in this book, it is also clear from the analysis of early modern business networks of diamond traders, see Vanneste, Global trade, pp. 81-84. For a theoretical discussion on self-interest as cultural construct, see ibid., pp. 14-20.

NACS, $\mathrm{N}^{\circ} 330$, '2 2 e Replicq van dhn Clement van Sanen \& $C^{\circ}$ ', Izmir, o7/o2/1764. 
were shareholders in the vessel. Pieter Ouckama was charged with finding a return cargo for that ship in Izmir. ${ }^{169}$ In his letter, Pieter van Sanen admitted he had spoken to Ouckama in an attempt to load the goods he already had, such as the cotton, on Horneer's ship, in which they had a share, instead of on the Vrouwe Berendina. Their argument was that the former was already onethird loaded and there was a shortage of merchandise on the quays in Izmir. If Ouckama agreed to load on Horneer's ship, he could demand Zeegenberg make an intra-Mediterranean journey. Van Sanen promised to help procure a return cargo for Zeegenberg in the meantime. This way, both ships would arrive in the United Provinces faster than they would have without this mutual assistance. ${ }^{170}$

This was an important letter, as it rebuffed Ouckama's accusation that van Sanen had acted out of self-interest in detail. To the contrary, he argued that he had thought of a construction that would help himself, Ouckama and both of their principals in the United Provinces. It was a proposal that was fully congruent with the merchants' style, and the reciprocity it dictated was explicitly mentioned by van Sanen when he wrote that 'when Zeegenberg returned, [I] would have helped him reciprocally' ${ }^{171}$ Van Sanen felt that Ouckama had ignored this good idea because of a growing personal antipathy towards van Sanen, which seemed to have blurred his good vision. ${ }^{172}$ It was a big mistake to make, especially considering the importance of supplying reciprocity. Trade could indeed not exist when its participants only relied on their self-interests. But in this case, it was Ouckama's personal sentiment that apparently got in the way of good (i.e., reciprocally advantageous) business. It turned out that the shipping suggestions of van Sanen and his partners were not so ill-advised. The Jonge Jacob, Horneer's vessel, left Izmir before 22 August, less than three weeks after the fire. Hilkes' Maria Dorothea left sometime between 22 August

169 There were problems with that return cargo on behalf of Abraham Musquetier and Sirp Ouckama because of the same fire that led to the dispute with Wijnants \& Cramer, which led to a separate court case. See NACs, $\mathrm{N}^{\circ} 336$ ('Ouckama \& $\mathrm{C}^{\circ}$, Nederlandse kooplieden te Smyrna, tegen A. Musquetier, koopman te Leiden, $1766^{\prime}$ ), 'Copije depositie van Sirp Ouckama d'Amstm weegens d'intresten van Ab:m Musquetier te Leijden met Ouckama \& $\mathrm{C}^{\circ}$ alhier', Amsterdam. The document was stamped by the burgomasters of Amsterdam on 23 May 1766 and received in Izmir on 7 July 1766.

170 NACs, $\mathrm{N}^{\circ} 33$, 'Antwoord van dhr P: van Sanen particulier aan P. Ouckama weegens onderlinge vriendschap', Izmir, o7/02/1764.

171 Ibid., '[...] als capt Zeegenberg weederom quam zouden hem weeder reciproquelijk helpen $[\ldots]$ '.

172 Ibid. 
1763 and 22 February 1764, similar to Leuning's ship. Zeegenberg's Vrouwe Berendina only left between 22 February and 22 November later that year. ${ }^{173}$

The litigants agreed on one thing: the twenty-four bales could indeed have been shipped earlier, and the discussion in court continued by the addition of a declaration made by Wijnants \& Cramer about the damaged cotton, supported by extracts of correspondence between them and Ouckama. The latter had indeed stored sixty bales of cotton in his warehouse, first forty and then twenty more. After the fire, he sent an account for the sixteen that had been damaged during the fire. This was not disputed; only the matter of who should carry the financial responsibility was disagreed upon. The story was different for the twenty bales, all marked with the logo of Wijnants \& Cramer. These twenty were part of a quantity of forty-eight bales that had not been stored in the warehouse yet but in the passage that gave access to it. According to Ouckama's correspondence to Wijnants \& Cramer, he had thrown them in the water before the fire had reached the warehouse, which suggested they had not been burned. Ouckama stated they had been damaged by falling debris, in the form of burning nails and wood, something Wijnants \& Cramer found unlikely considering they were wet. But worse was the fact that Ouckama claimed to have done his utmost to recuperate as many of the bales as he could from the water but that several had been stolen. Wijnants \& Cramer found it most bizarre that none of the recovered cotton carried their logo. More absurd was Ouckama's explanation that the debris had burned the cotton bales exactly at the place of the markings. They concluded that Ouckama had forged accounts and lied about the true ownership of the cotton. The lost cotton could not have been theirs, and thus they could not be held responsible. ${ }^{174}$

These were very severe accusations, in a case that already had become quite emotional, and Ouckama specifically wanted to write a personal statement to address the remarks made by Wijnants \& Cramer about the seeming paradox of cotton being burned while being thrown in the sea at the same time, just as van Sanen had done almost three weeks earlier. For him, the Amsterdambased firm was deliberately using 'confused language, cowardly evidence and

173 Heeringa and Nanninga, Bronnen tot de geschiedenis, 3: pp. 764-773, 'De waarde der goederen, die door de nationale en door de vreemde handelshuizen te Smirna zijn ingevoerd en uitgevoerd met Nederlandsche schepen, geboekt in de periode 22 augustus $1760-22$ augustus 1765 '.

174 NACS, $\mathrm{N}^{\circ} 33$ o, 'Remarkes der heeren Wijnantz \& Cramer over de reek: \& reek: courant \&a van de hn Ouckama \& $\mathrm{C}^{\circ}$ vertoond op o7/o2/1764'. These remarks, written in Amsterdam at an unknown date, were shown in court on $07 / 02 / 1764$. 
false conclusions.' ${ }^{175}$ Pieter Ouckama did not accept the accusations of forgery and deceitful keeping of books and labelled Wijnants \& Cramer's arguments as 'erroneous talk, follies' and even as 'fake evidence' - 'a disgrace for such merchants.'. ${ }^{176}$ This makes perfect sense, as his reputation as a merchant and commission agent was on the line, which is why he defended himself so forcefully; he ended by stating that it he would have preferred not to react to such 'childish expressions and reflections' but that he felt obliged to 'reveal their disgrace' to the court. ${ }^{177} \mathrm{He}$ concluded with a cynical address to the consul personally, excusing himself for bothering him with this matter but that the consul should 'thank' ('danken') Wijnants, Cramer, Clement, van Sanen and van der Zee, as they were all embarrassed, 'not knowing how to behave, to give an appearance of legality to their case.'178

One day later, most of the arguments Ouckama had made in his personal statement were repeated in a new counter-reply made by the firm of Ouckama \& $\mathrm{C}^{\circ} .179$ The words remained passionate, and Wijnants \& Cramer were accused of calling Ouckama \& $\mathrm{C}^{\circ}$ dishonest, without bringing any evidence, a very severe accusation, particularly when made in a public space. ${ }^{180}$ The court felt that perhaps the tone was getting a bit out of hand. In the margin of the text, a message from the consul had been written down, which stated that Clement, van Sanen, van der Zee \& $\mathrm{C}^{\circ}$ had ten days to come forward with a new reply but had 'to avoid all scandalous and offensive expressions, and that no more unorderly and legally unfitting writings and expressions, which have been used thus far, will be allowed'.181

For the consul, both parties were getting carried away, something the two parties accused each other of as well. Both parties argued their case in the

175 NACs, $\mathrm{N}^{\circ} 33$, 'Contra remarkes van Ouckama \& $\mathrm{C}^{\circ}$ op de remarkes van Wijnants \& Cramer weegens de verbrande cattoen', Izmir, $27 / 02 / 1764$, ' $[$... $]$ verwarde taal laff bewys $\mathrm{X}$ valsche conclusie [...]'

176 Ibid., ‘[... mis praaten, gekheeden [...] x valsche bewyzen [...]' and '[...] het is schande voor zulke cooplieden [...]'.

177 Ibid., '[...] kinderagtige gezegdens reflectien [...]' and '[...] om aan uw ed gestr hunne schande bloot te stellen [...]'

178 Ibid., '[...] niet weetende hoe het te draagen, om schyn van regt aan hun zaak te geeven $[\ldots]$ '.

179 NACS, $\mathrm{N}^{\circ} 330$, ' 3 e replicq van Ouckama \& Comp weeg Wijnantz \& Cramer', Izmir, 28/o2/ 1764 .

180 Ibid. The firm felt that dishonesty was the most unfriendly accusation one could possibly make. See pp. 179-180.

181 Ibid., '[...] met versuijminge van alle skandaleuse en aenstottelyke termen also afkomstig gene sulke onordentelijke en in regte onbetaemelijke geschriften \& uijtdrukkinge, gebruijkt zijn van parthijen sullen worden g'admiteerd'. 
conviction they were right, or at least in the realisation that it was important to escape both legal and financial responsibility for the damaged goods. It can only be expected for a legal argument to become somewhat heated. ${ }^{182}$ While using forms of economic rationality that had to do with the calculation of risk, and consideration of one's own interests against those of both the competition and collaborators, merchants in the early modern period also operated within a sociocultural context that allowed for emotions in business. Ties were forged partially based on kinship, the sharing of religion or nationality, trust and reputation. These criteria for cooperation can be situated in some sort of overlapping area in which the impersonal nature of the modern market exchange coincided with the personal nature of individual transactions. This area was the framework within which early modern merchants operated, and while it is impossible to guess their thoughts, most of the material that survived regarding business letters, memoranda, etc. demonstrates clearly that emotions and passions were part of the nature of business. ${ }^{183} \mathrm{~A}$ similar argument was made by Emma Rothschild when she analysed Turgot's writings on a famous case brought before the criminal jurisdiction of Angoulême in 1769 , when several bankers were accused of charging usurious interest rates. While historians and economists have looked mostly at the theoretical parts of Turgot's Mémoire that dealt with the matter, Rothschild argued for the importance of understanding the presence of sentiment and emotion in economic history. ${ }^{184}$

Several eighteenth-century economic thinkers were concerned with the role of commerce in softening the passions of men. Montesquieu wrote in his Esprit des Lois that 'commerce [...] polishes and softens barbarian ways as we can see everyday'.185 But, in times of expanding international trade, the idea of commerce in itself was not sufficient to tame the more violent passions of men. Commerce could also corrupt society and destroy its fabric based on religion and traditional hierarchies, some argued, through the quest of traders to strive for their own enrichment. Commerce could even harm society by bringing in foreign elements and merchandise, as well as foreigners, considered a

182 Others used similar emotional language; see several of the case studies in chapters four and five, passim.

183 Vanneste, Global trade, pp. 81-91.

184 Emma Rothschild, 'An alarming commercial crisis in eighteenth-century Angoulême: Sentiments in economic history', Economic history review, 51:2 (1998): pp. 268-293.

185 Quoted in Albert O. Hirschman, The passions and the interests - Political arguments for capitalism before its triumph (Princeton, 1977), p. 6o. 
negative development by various contemporary thinkers. ${ }^{186}$ The debate over the relationship between commerce, politics and society goes back a long way and was certainly not restricted to the eighteenth century. ${ }^{187}$ The expansion of international trade during the seventeenth and eighteenth centuries added a new dimension to the debate, and several thinkers constructed a worldview in which trade could fulfil a positive and constructive role in society and within human relationships, thereby opposing those believing the opposite to be true. Jean-Jacques Rousseau, Adam Smith, Bernard Mandeville, Edmund Burke and others all considered the position of trade in society and the nature of the men who formed society. ${ }^{188}$ Two main visions were put forward. From a negative point of view, trade would destroy traditional and harmonious society by promoting selfish values and foreign involvement. Charles Davenant $(1656-$ 1714) wrote that 'trade, without doubt, is in its nature a pernicious thing; it brings in that wealth which introduces luxury; it gives rise to fraud and avarice and extinguishes virtue and simplicity of manners.'189 In a positive assertion,

186 See, for instance, J.G.A. Pocock, Virtue, commerce, and history. Essays on political thought and history, chiefly in the eighteenth century (Cambridge, 1985) for an analysis of the challenges the expansion of trade brought to politics; see also the essays in Istvan Hont and Michael Ignatieff, eds., Wealth and virtue - The shaping of political economy in the Scottish enlightenment (Cambridge, 1983); and Albert O. Hirschman, 'Rival interpretations of market society: Civilizing, destructive, or feeble?', Journal of economic literature, 20:4 (1982): pp. 1463-1484. For a discussion on negative and positive aspects of trade, see Vanneste, 'Commercial culture', pp. 14-32.

187 For an analysis, see Schröder, Trust in early modern international political thought, pp. 199-218.

188 See, for instance, Jean-Jacques Rousseau, Les confessions, suivies des rêveries du promeneur solitaire (Genève, 1782); Edmund Burke, Reflections on the revolution in France, and on the proceedings in certain societies in London relative to that event. In a letter intended to have been sent to a gentleman in Paris. By the right honourable Edmund Burke (London, 1793) for rather negative visions on trade and self-interest; and Josiah Child, A new discourse of trade: Wherein are recommended several weighty points, 4th ed. (London, [1745?]); Bernard Mandeville, The fable of the bees, or, private vices, public benefits (London, 1714); JeanFrançois Melon, A political essay upon commerce. Written in French by monsieur $M^{* * *}$. Translated, with some annotations, and remarks. By David Bindon, Esq (Dublin, 1738); and, of course, Adam Smith, An inquiry into the nature and causes of the wealth of nations (London, 1776) for a more positive approach, which led to the idea of homo economicus and classical economics. For criticism of this model, see Geoffrey Ingham, 'Some recent changes in the relationship between economics and sociology', Cambridge journal of economics, 20:2 (1996): pp. 243-275.

189 Charles Davenant, 'Essay upon the probable methods of making a people gainers in the balance of trade', in The political and commercial works of the celebrated writer Charles D'Avenant, LL.D. relating to the trade and revenue of England, the plantation trade, the East-India trade, and African trade. Collected and revised by Sir Charles Whitworth, etc. (Farnborough, 1967), 2: p. 275. 
commerce would do exactly the opposite, and a commercial society was also a peaceful society that could not be ruled by a despot without taking the desires and needs of his subjects into account. When a Jewish diamond trader wrote an anonymous pamphlet to defend the idea of the naturalisation of Jews in England, one of his main arguments was the utility of the Jewish diaspora as traders. ${ }^{190}$

Both those who defended and those who attacked commerce could agree on one thing: societies needed laws so individual passions could be directed towards contributing to the public good. Jean-François Melon wrote in the 173 os that 'if men were so happy, as to regulate their actions, according to the pure maxims of religion, they would not have occasion for laws. Duty would serve, as a curb to vice, and an incitement to virtue. But, unhappily for us, we are swayed by our passions, and the legislature should only endeavour, to turn them to the best advantage of the community'.191 This applied to society in general but also to well-regulated commerce, something that was clearly recognised by the Dutch ambassador in Istanbul, Elbert de Hochepied, in 1754, when he had his ideas on Levant trade put to paper in a Mémoire: 'men need laws to oblige them to practice that what is essential to their communal happiness, traders are essentially in need of them, they form the main body of the state, particularly in the United Provinces'.192 De Hochepied was an advocate of trade and recognised its importance for the United Provinces as a state. He was of the opinion that it was the traders' habit to exalt freedom in commerce but, he added, too few of them paid attention to the fact that this freedom

190 Philo-patriae, Considerations on the bill to permit persons professing the Jewish religion to be naturalized by parliament (London, 1753); and Further considerations on the act to permit persons professing the Jewish religion, to be naturalized by parliament (London, 1753). The link made between commerce and Jews has often been used in anti-Semitic tropes and persisted over time, finding its way into academia as well. For an analysis, see, for instance, Benjamin Braude, 'The myth of the Sephardi economic superman', in Trading cultures: The worlds of western merchants, eds. Jeremy Adelman and Stephen Aron (Turnhout, 2001), pp. 165-194 and the references therein; as well as Benjamin Arbel, 'Jews in international trade: The emergence of the Levantine and Ponentines', in The Jews of early modern Venice, eds. R.C. Davis and B. Ravid (Baltimore and London, 2001), pp. 73-96. Francesca Trivellato has rightfully remarked that '[...] depictions of Jewish economic roles test the inclusivity of the Enlightenment trope of commerce as sociability'; Trivellato, The promise and peril of credit, p. 130.

191 Melon, A political essay upon commerce, pp. 173-174.

$192 \mathrm{NA}, \mathrm{N}^{\circ}$ 2.21.006.46, $\mathrm{N}_{2} 2$ ('Mémoire pour le commerce', 1754 ), $\mathrm{f}^{\circ} 4 \mathrm{r}$, '[...] il faut aux hommes des loix pour les obliger à pratiquer ce qui est essential à leur bonheur commun, les commerçans en ont essentiellement besoins, ils forment le corps principal de l'état, surtout dans les Provinces Unies'. 
caused disorder, which harmed the state. Freedom in trade, he continued, had to be limited by the state so the merchant's quest for individual profit would benefit the state. ${ }^{193}$ This was the authorities' general attitude towards trade and a reason why commercial structures were developed by the state. ${ }^{194}$

It is no surprise then that the ambassador's nephew, Daniel Jean de Hochepied, consul in Izmir and thus responsible for adjudicating commercial disputes between Dutch merchants, aimed to preserve clear legal proceedings without the ballast of statements made by merchants about one another that were too passionate. Trade was crucial, and merchants had to be allowed to operate within a clear framework that allowed them to flourish. Limiting litigation, or at least restricting it to clear legal arguments that could be judged by the consul, assisted by his assessors who were, as fellow merchants, peers of the litigating parties, was a crucial part of this. Reflections on the regulating role the state should play in the world of international commerce were also behind efforts authorities made to enable a legal environment within which traders could litigate, even if the litigation itself took place on the basis of an operational context that was shaped by the merchants' style.

\subsection{International Support for the Merchants' Style}

In the trial between Ouckama and Wijnants \& Cramer, litigation continued by turning to international merchant custom as confirmed by a group of traders from different backgrounds. The increasingly heated tone of both parties made it clear that the case was far from resolved, and in March 1764, the consul

193 Ibid. This was the authorities' general attitude towards trade and a reason why commercial structures were developed by the state. In the United Provinces, cities competed with one another to attract trade through the development of an institutional framework, see Gelderblom, Cities of commerce. Mercantilist policies can be considered a form of economic competition between states, a competition that grew throughout the early modern period. See Oscar Gelderblom, 'The organization of long-distance trade in England and the Dutch Republic, 1550-1650', in The political economy of the Dutch Republic, ed. Oscar Gelderblom (Farnham, 2009), pp. 223-254; and M.N. Pearson, 'Merchants and states', in The political economy of merchant empires, ed. James Tracy (Cambridge, 1991), pp. 41-116. For a profound analysis of trade, nations and economic thinking in the eighteenth century, see Istvan Hont, Jealousy of trade. International competition and the nation-state in historical perspective (Cambridge, MA and London, 2005).

194 Emma Rothschild, Economic sentiments - Adam Smith, Condorcet, and the Enlightenment (Cambridge, MA and London, 2007), p. 72. Providing assistance to the state was one of the motivations behind the developing field of political economy. See Terence Hutchison, Before Adam Smith - The emergence of political economy, 1662-1776 (Oxford and New York, 1988); and for an eighteenth-century example, Etienne Bonnot (Abbé de Condillac), Commerce and government considered in their mutual relationship, trans. Shelagh Eltis (Indianapolis, 2008). 
requested the opinion of French, English and Dutch firms in Izmir about the responsibility for damaged merchandise in a transaction between an agent and a principal. Most argued that it differed from case to case, particularly based on whether a specific order had been given, but that generally the agent was responsible. ${ }^{195}$ That these declarations were collected by the plaintiffs did not seem to have affected their legal status. It is remarkable that even in a case involving only Dutch traders, the only evidence that was used outside of the respective traders' business papers and their declarations was a declaration by non-Dutch merchants. This, in combination with the various references to the merchants' style in the declarations, forms an important indication that a reliance on merchant custom was much more prevalent in legal procedures than a reliance on some formal, national body of law. In none of the more than thirty documents brought into this case was any reference made to Dutch law. The argumentation centred on responsibility according to the terms set by merchant custom, which had to be determined from the reasoning of the litigants, and additional declarations by the merchant community as a whole. This was an international matter because merchant custom was international, and in the legal reasoning, the nationality of the litigants did not play any role. It was normal for courts to rely on declarations from experts as evidence, particularly in courts dealing with commercial disputes - a judge, such as the consul, could not be expected to be aware of all current merchant custom. A reliance on merchants, either as assistant-judges or as outside experts, was crucial to a good functioning court. ${ }^{196}$

The use of expert declarations is directly related to adjudication on the basis of unwritten rules and custom. A litigant could question the legitimacy of the rule in question, which was considered proven in case a group of knowledgeable persons issued a declaration confirming the rule or custom. Such a declaration was called a turbe. ${ }^{197}$ For Oscar Gelderblom, the use of turben in court was 'legislation from below', which revealed 'how sensitive urban magistrates, in this case from Antwerp and Amsterdam, were to demands from merchants'.198 Turben had indeed also spread to Amsterdam, and the earliest example of their

195 NACs, $\mathrm{N}^{\circ} 330$, 'Parere van Clement van Sanen van der Zee \& $\mathrm{C}^{\circ}$ weeg: de differentie met Ouckama \& $\mathrm{C}^{\circ}$, Izmir, 21/03/1764.

196 For a recent historical overview on the role of experts in the Anglo-Saxon legal system, see Déirdre Dwyer, The judicial assessment of expert evidence (Cambridge, 2008).

197 See p. 110. For a contemporary discussion on the rules concerned with proving custom in the Dutch context, see Decker, Het Roomsch Hollandsch recht 1: pp. 30-31.

198 Gelderblom, Cities of commerce, p. 99. The use of expert declarations can be found in other commercial cities as well. For Venice, see Fusaro, Political economies, pp. 180-181. 
use there dates from 1554, where they were used to deal with issues of payments to be made by creditors. ${ }^{199}$ One of the discussions included in J.M. Barels' compilation of advice regarding trade and maritime navigation from 1781 centred on the relationship between principal and agent. Barels stated that no one could take any action or make any claim on merchandise in the hands of an agent unless the agent had been paid for what he was due. The reason behind this custom was the importance of commission trade and the central role of the agent, which needed to be protected. According to Barels, this rule was 'according to the notorious customs and usages generally observed amongst merchants', and it was confirmed in Amsterdam by a turbe from $1591 .{ }^{200} \mathrm{~A} \mathrm{com-}$ pilation of turben concerning commercial matters, published in Amsterdam at the end of the eighteenth century, was considered an important collection and was used to save time in court. The preface indicated that turben were used to avoid lengthy and costly procedures. Although they were considered as less crucial than laws made by sovereigns, they were founded on the basis of 'reason and equity' and were 'accepted by venerable courts'. ${ }^{201}$ Because the drafting of such declarations took time, it was agreed in 1788 that merchants would only sign a turbe if it was clear that a copy of it would go to the publisher of the Verzameling van casuspositien. ${ }^{202}$ Most interestingly, some of the declarations on the merchants' style issued by merchants in Izmir in legal disputes were not only signed by Europeans but also by Ottomans. ${ }^{203}$

The inclusion of Ottomans as experts or witnesses in European courts was neither very common nor exceptional. The case files in this dispute contain three translations concerning the registration of the payment of Ottoman export duties, the bid'a, on forty-eight bales of cotton delivered to Ouckama's warehouse the day before the fire. One came from an Armenian trader, Aszadur di Balta, who had received Ouckama's order to pay in cotton and who was one of the abovementioned Ottoman intermediaries. The second was a declaration by Mustapha, a scribe at the office for the bid'a on cotton in Izmir,

199 Handvesten, privilegien, octroyen, costumen en willekeuren der stad Amstelredam (Amsterdam, 1663), p. 187.

200 Barels, Advysen over den koophandel en zeevaert, 1: p. 78, ‘[... ] alles agtervolgens de notoire costumenen usance onder de kooplieden alomme geobserveerd wordende, en waer van binnen deeze stad Amsterdam by forme van turbe bereids gedaen en verklaeringe genomen is in den jaere 1591 '.

201 Verzameling van casuspositien, 1: pp. iii-iv, '[...] op de reden en billykheid gegrond [...] door zeer venerabele rechtbanken zyn aangenomen $[\ldots]$ '.

202 Ibid., p. v. This is a confirmation of the legitimacy of such compilations as sources for commercial law as argued by Lichtenauer. See pp. 109-110.

203 For an example, see figure 8. 
confirming the forty-eight bales had been registered, which was confirmed by a declaration in Hebrew by three Jewish men who also worked for the Ottoman tax office. ${ }^{204}$ The declaration of the men working at the bid'a, including one who was perhaps a Muslim man called Yūsuf, demonstrates that in a matter in which Ottoman-European relations were not at stake, it was not difficult to obtain official declarations from individuals within Ottoman fiscal structures, showing a willingness from Ottoman officials to cooperate with European demands, as long as they did not interfere with the functioning of Ottoman institutions. ${ }^{205}$

In March 1764, Ouckama was finally allowed to take an oath on the veracity of his earlier declarations, something he had insisted on giving but which he had not been allowed to do. The oath was not taken lightly, as it could be a crucial factor in determining the trial's outcome. On the fourteenth, Ouckama physically appeared before the consul, who agreed that the oath had become necessary, as Ouckama's honour and reputation were at stake. ${ }^{206}$ It was taken one day after Ouckama sought the opinion of various merchants from Izmir on the whole matter. While Clement, van Sanen, van der Zee \& $\mathrm{C}^{\circ}$ had obtained a similar declaration in favour of Wijnants \& Cramer, Ouckama managed to obtain signatures from several firms that had first testified on behalf of Wijnants \& Cramer but changed their minds, and he also managed to obtain several more, seventeen in total, from Frenchmen, Italians, one Armenian and the Dutch firms of David van Lennep \& Enslie and Panaiotis \& de Vogel (see figure 7). ${ }^{207}$ They all felt that Ouckama could not be blamed for using his own money to buy cotton for others, a fact used by the plaintiffs to argue it was Ouckama's cotton and not theirs. They further stated that, once the principal trader abroad had requested certain purchases, and his agent was keeping him informed about the process, the principal had to take full responsibility for them. It was both an argument of reason and fully in line with commercial practices that existed within the larger mercantile community, and the argument was well received by the consul. Together with the assessors, the consul finally reached a verdict in May 1764. Remarkably, one of assessors assisting on

204 NACs, $\mathrm{N}^{\circ} 33$, 'Traductie van een Armeens en een Turks att: weeg: de bewuste 48 verloore B: cattoen van Ouckama \& $\mathrm{C}^{\circ}$, Izmir, $27 / 02 / 1764$; and NACS, $\mathrm{N}^{\circ} 33$, 'Traductie van een hebrees att: van den Bedaetgi der catt: dat Ouckama \& $\mathrm{C}^{\circ}$ dags voor de brand 48 B: cattoen heefft ontfange', Izmir, 27/02/1764.

205 See also note 32 on p. 274.

206 NACs, $\mathrm{N}^{\circ} 33$, 'Acte van de beeedigde declaratoir van P. Ouckama weegens zijn directie in de brand gehouden \&a', Izmir, 14/o3/1764.

207 NACs, $\mathrm{N}^{\circ} 33$, 'Request van Ouckama \& $\mathrm{C}^{\circ}$ tot geleijde van eene parere', Izmir, 13/o3/1764. 
the case was Dirk Knipping, Ouckama's former business partner, while another was William Enslie, who had signed the merchants' declaration that was in Ouckama's favour. Normally, Pieter van Sanen should have been assisting in this case as assessor as well, but considering he was acting on behalf of the plaintiff, he was excused.

At several stages during the trial, merchants were demanded to give their opinion - as assessors assisting in the adjudication but also as experts offering declarations of their interpretation of commercial custom. Before agreeing on a verdict, the consul and assessors submitted all the paperwork involved in the case to three neutral persons, all merchants. They remained unnamed in all of the documentation, but their judgment was considered important in the process of reaching a final sentence, which concluded that justice and equity is in aspects on the side of the gentlemen Ouckama \& $\mathrm{C}^{\circ 208}$ Equity had indeed been an important consideration: 'considering that those gentlemen [Wijnants \& Cramer], if all had ended well, would probably have gained a considerable profit, and considering that they would have enjoyed that profit all alone, without sharing with Ouckama \& $\mathrm{C}^{\circ}$, so it seems just to us that they would have to carry and suffer all by themselves also the damages that came from above, without guilt of the gentlemen Ouckama \& $\mathrm{C}^{\circ}{ }^{\circ}{ }^{209}$ The latter firm had 'defended and justified itself in all the necessary matters, in decent form, and with many demonstrations of truth. ${ }^{210}$ Clement, van Sanen, van der Zee \& $\mathrm{C}^{\circ}$ were given thirty days to pay the money that Wijnants \& Cramer owed, as well as all legal expenses. ${ }^{211}$

The acquittal of Ouckama \& $\mathrm{C}^{\circ}$ and the confirmation of the liability of the principal are not remarkable and can be considered as evidence of the changing perceptions of European ius commune under the pressure of expanding trade. When international trade grew, the role of the agent became crucial. Roman law had no general concept of agency and did not recognise contracts made on behalf of third parties - even though situations involving middlemen

208 NACs, $\mathrm{N}^{\circ} 33$, 'Sententie van de heeren consul \& assessooren in de differentie van dh:n Clement v. sanen van der Zee \& $\mathrm{C}^{\circ}$ met dh:n Ouckama \& $\mathrm{C}^{\circ}$, Izmir, 23/05/1764, '[...] soo is het regt en billijkhijd in allen deelen aen de zijde van de heeren Ouckama \& $\mathrm{C}^{\circ}[. .$.$] '.$

209 Ibid., '[...] considereerende dat die heeren, in dien alles wel affgeloopen was, en seer vermoedlijk een aensienelijke winst hadden affgeworpen, die winst alleen souden hebben genooten sonder de selve met de heeren ouckama \& comp te deelen, soo schijnd het ons meede billijk dat zij de schaade als van hoogerhand sonder schuld van de heeren ouckama \& $\mathrm{C}^{\circ}$ gekoomen daar van ook alleen moeten draagen x lijden'.

210 Ibid., '[...] haer in alle het noodige in soo behoorelijke forma, en met soo veel blijken van waerhijd, hebben verdeedigt en geregtvaerdigt [...]'

211 Ibid. 
were acknowledged. ${ }^{212}$ The use of agents in international trade created a situation in which there were two legal arrangements instead of one - between the principal and the agent and between the agent and the buyer/seller. According to Reinhard Zimmermann, seventeenth-century Dutch scholars, influenced by natural law, developed the concept of the principal's liability in both arrangements, and they did so 'from the point of view of commercial practice and the mores hodierni'. ${ }^{213}$ Thus, the concept of liability in the relationship between principal and agent had developed in spite of its absence in the Roman legal tradition and under pressure from the practices attached to early modern international trade. Adjudicating matters of liability for damage to merchandise in light of the principal-agent relationship is therefore not only a judgment about one of the most crucial characteristics of international trade, it is also a clear example of how the merchants' style came to full fruition as an internationally accepted legal concept situated between custom, as arising out of commercial practice, and law, as inspired by the context of ius commune but not limited by it. One can even argue that early modern juridical assessments of commercial agency led to a codification of the concept in the nineteenth century.214

It was not uncommon for the losing party to appeal, and they would generally do so by registering a demand for appeal at the consular court, after which, theoretically, the appeal procedure could start. This is what Clement, van Sanen, van der Zee \& $\mathrm{C}^{\circ}$ decided to do, and they sent a request for appeal, to be litigated 'before higher judges, where it should be treated.' ${ }^{215}$ The general reference to higher judges, without specifying a particular court, was common amongst demands for appeal and might suggest that it was not always immediately clear which court was qualified to deal with the appeal. There were a number of seventeenth-century regulations, issued by the States General, clarifying which court had jurisdiction for appeals. According to a law issued in February 1686, the verdict of a case brought before the consular court that only involved traders from Holland could be appealed before the Hof van Holland or the Hoge Raad. Should there be other Dutchmen involved, particularly as defendants, the appeal had to be brought before the States General instead. ${ }^{216}$

212 For a detailed overview of Roman legal concepts of agency and third-party involvement and early modern changes, see Zimmermann, The law of obligations, pp. $45^{-5} 8$.

213 Ibid., p. 57. 'Mores hodierni' means modern manners.

214 Ibid., p. 58.

215 NACs, $\mathrm{N}^{\circ} 33$, 'Appel der heeren Clement van sanen van der zee \& $\mathrm{C}^{\circ}$ op de sententie van 25 meij 1764', Izmir, $28 / 05 / 1764$, '[...] voor hooger regters alwaar zulks dienen moeten'. For appeals, see pp. $265^{-272}$.

216 See pp. 266-267. The States General's sentencing relied on the advice issued at either the Hof van Holland or the Hoge Raad. 
But in reality, there were hardly any cases brought before the Dutch consul in Izmir that only involved Dutchmen, and even less in which the litigants all came from Holland. Neither in the archives of the Hof van Holland, nor in those of the Hoge Raad, appeal cases on consular verdicts can be found. There were, however, a number of appeals that involved traders who were active in the Levant and who had been involved in litigation before a lower court in the United Provinces.

The archives do not reveal further traces of the appeal made by Clement, van Sanen, van der Zee \& $\mathrm{C}^{\circ}$. The consul had accepted it under the condition that the sentence would be executed first, as stipulated in the February 1686 regulations. ${ }^{217}$ The most interesting thing the request to appeal demonstrates is the grounds for appeal invoked in it: 'we the underwritten [Clement, van Sanen, van der Zee \& $\mathrm{C}^{\circ}$ ] have proven sufficiently in our delivered writings that these gentlemen Ouckama \& $\mathrm{C}^{\circ}$ have, in this case, acted beyond their orders and disregarded the merchants' style. 218

Intra-Dutch litigation, as discussed in the cases in this part, was rare. Most cases involved a foreign plaintiff, and in the cases in which both litigants were Dutch, the plaintiff generally resided in the United Provinces, a consequence of the fact that Dutch Levant trade was commission trade - if a Dutch merchant was tried as defendant before the consular court in Izmir, it was often because a commission was disputed. Evidence shows that in none of these intra-Dutch disputes was there any mention of Dutch written law, except in arguments about procedure or the court's jurisdiction. The only concrete references these parties made were to the merchants' style, and these were regularly very specific and found explicit support through the declarations of experts. The latter were often foreign, and there were no indications that the nationality of the litigants was relevant for the trial. Dutch litigants who were tried by the Dutch consul in Izmir were merchants first and Dutchmen second. It was only when Ouckama complained that he was not helped by a fellow national during the August fire that nationality seems to have played a role in legal reasoning. In this case, it stood opposite the merchant custom of reciprocity, as was argued by Clement, van Sanen, van der Zee \& $\mathrm{C}^{\circ}$. The lack of importance given to nationality by Consul Daniel Jean de Hochepied was never considered strange. ${ }^{219}$

217 NACs, $\mathrm{N}^{\circ} 33$, 'Appel der heeren Clement van sanen van der zee \& $\mathrm{C}^{\circ}$ op de sententie van 25 meij 1764', Izmir, 28/05/1764.

218 Ibid., 'Wy ondergeschreeven genoeg aangetoondt hebben in onse overgeleeverden geschriften deesen heeren Ouckama \& $\mathrm{C}^{\circ}$ in deesen saak buyten orders $\mathrm{x}$ coopmansteyl te hebben te werk gegaan $[\ldots]$ '.

219 See also pp. 171-172 and 26o-261. 


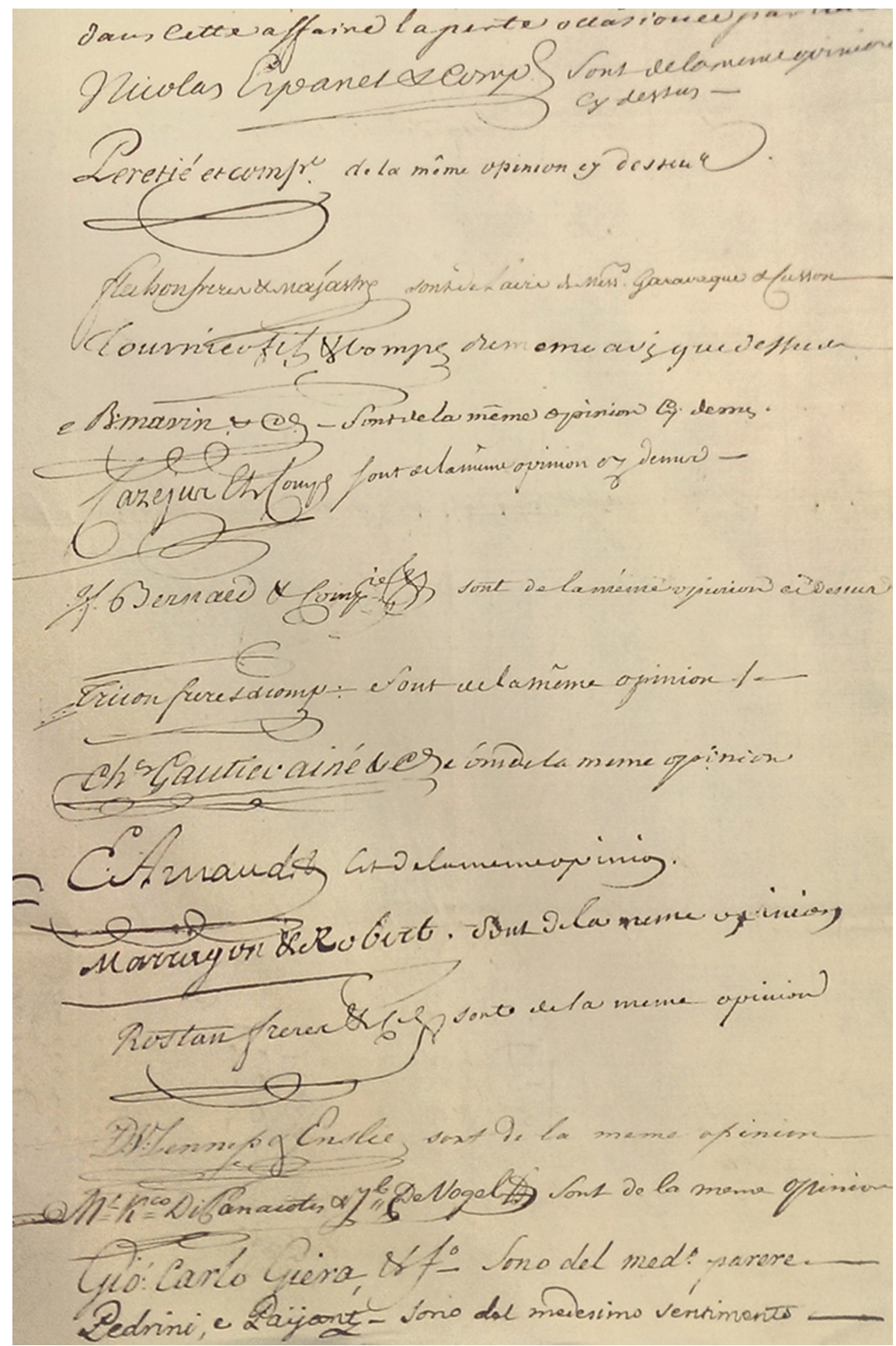

FIGURE 7 Signatures of merchants on an opinion [parere] in support of the argument of Pieter Ouckama, 13 March 1764 FROM THE DUTCH NATIONAL ARCHIVES, THE HAGUE (ARCHIVES OF THE DUTCH CONSULATE IN SMYRNA). PHOTO BY THE AUTHOR. 
The ease with which merchants issued powers of attorney to ensure legal representation at a court far away is remarkable and further testimony to the successful integration of the merchants' style - here, expressed by the apparent, self-evident acceptance of powers of attorney as a commercial favour into legal procedure. It is harder to estimate whether geographical distance played a role in punishment. Wijnants \& Cramer was a firm established in Amsterdam, and both partners most likely never set foot in the Levant. The court's sentence, of course, led to a losing party who was made to pay. But the consul in Izmir could not force Wijnants \& Cramer to pay. Should they refuse, the opposite party only had two options to force them: The first was the legal option, having their assets sequestered; the second was found in the merchants' style. A trader hoping to remain in business could not afford to ignore a legal verdict. In addition to legal and commercial pressure to force traders into compliance, there was also a social option that applied within merchant communities. Social forms of punishment for cheating traders existed when community leaders were bestowed with adjudicating powers. This was the case for several foreign trading communities in which unity was based on religion, such as the Jewish diaspora, but it also applied to European national trading communities in the Ottoman Empire, whose consuls equally had been bestowed with adjudicating powers by a host society. Some Dutch traders received forms of social sanctioning - although this seems to have been a very uncommon measure. Dirk Knipping, for instance, was thrown out of a partnership and ended up living in the Armenian neighbourhood (see figure 4). ${ }^{220}$ Other Dutch nationals were (temporarily) stripped of their Dutch national status because of infractions they had committed - a fate that befell several partners of the firm of Clement, van Sanen, van der Zee \& $\mathrm{C}^{\circ}$, who had become involved in official Prussian Levant trade and even took up diplomatic posts for Prussia. ${ }^{221}$ Gerrit van Brakel ended up being a social pariah for several years because he could not afford to fulfil the financial requirements of a negative verdict. ${ }^{222}$ It seems, then, that a plaintiff abroad had sufficient faith in his legal representative and the merchant community at large that a favourable sentence would indeed be upheld - and there could be social repercussions if a verdict was not respected. The options at the court's disposal to settle intra-Dutch disputes, including social ostracism, served less effectively in cases where one of the

\footnotetext{
220 See pp. 70-71 and 164.

221 See pp. 209-213.

222 See p. 237.
} 
litigants was not Dutch. ${ }^{223}$ Most court cases that the Dutch consul in Izmir adjudicated were international disputes between parties of different nationalities and religious affiliation.

223 Social ostracism as form of punishment for fraudulent merchants has often been studied in the context of diasporas, such as the Sephardic Jewish one. See, for instance, Yosef Kaplan, 'Political concepts in the world of the Portuguese Jews of Amsterdam during the seventeenth century: The problem of exclusion and the boundaries of self-identity', in Menasseh Ben Israel and his world, eds. Y. Kaplan, H. Méchoulan and R.H. Popkin (Leiden, 1989), pp. 45-62. It was a however a wider spread mechanism of punishment that was available to all foreign trading communities in a host society, and it is therefore unsurprising the Dutch in Izmir also made use of it. 